\title{
ACCESS TO HEALTH CARE AS AN INCENTIVE FOR HEALTHY BEHAVIOR? AN ASSESSMENT OF THE AFFORDABLE CARE ACT's PERSONAL RESPONSIBILITY FOR WELLNESS REFORMS
}

\author{
Lindsay F. Wiley ${ }^{1}$
}

I. Personal Responsibility for Wellness in the

Federal Health LaW LANDSCAPE 642

A. Personal Responsibility for Wellness: Conditioning Financial Incentives on Medical Compliance, Lifestyle Compliance, and Biometrics 645

B. Types of Health-care Coverage and Federal Regulation to Ensure Access.

1. Private Health Insurance ..............................648

2. Public Programs ...........................................650

II. The ACA's PeRsonAl RESPonsibility For WELLNESS

PROVISIONS

A. The 2013 RAND Report on Workplace Wellness Programs. 654

1. The Prevalence and Design of Workplace Wellness. 655

2. The Impact of Workplace Wellness Programs 665

B. The Group Health Plan Wellness Program Exception 666

1. The Wellness Program Exception in HIPAA ...669

2. The 2006 Wellness Program Rule

3. The Wellness Program Exception in the ACA ....679

1 The author is an Associate Professor of Law and Director of the Health Law \& Justice Program at American University Washington College of Law. The author wishes to thank the participants in the Indiana Health Law Review's 2013 symposium for their engagement and feedback on this project at an early stage when the RAND report and 2013 Rule had not yet been released, Nick Masero and Jillian Rubino for their research assistance, and the students in her spring 2013 and spring 2014 health law classes for grappling productively with wellness programs during a particularly grueling small group exercise. 
4. The 2013 Wellness Program Rule

C. Support for Small Business Workplace Wellness Programs

D. The Individual Insurance Wellness Program

Demonstration Project.

E. The Medicaid Incentives for Prevention of Chronic

Disease Program. 694

1. Federal Restraints on the Implementation of Incentive-based Personal Responsibility for Wellness Medicaid Programs. 695

2. Medicaid Wellness Program Waivers Prior to the $A C A$ 696

3. Medicaid Incentives for the Prevention of Chronic Disease Grant Program ...................................701

4. Post-ACA Medicaid Waiver Decisions ................ 705 III. CONCLUSION 708

Hundreds of thousands of lives have been saved by vehicle safety standards. ${ }^{2}$ For many years, the auto industry fought the adoption of even the most basic standards tooth and nail, arguing that driver responsibility was the key to preventing auto accidents. ${ }^{3}$ In doing so,

2 See, e.g., NAT'L HighWAY TrafFic SAFETy ADMIN., REP. No. DOT HS 809 833, LIVES SAVED BY THE FEdERAL MOTOR VEHIClE SAFETY STANDARDS AND OTHER VEHICle SAFETY TECHNOLOGIES, 1960-2002 PASSENGER CARS AND LIGHT TRUCKS - WITH A REVIEW OF 19 FMVSS AND THEIR EFFECTIVENESS IN REDUCING FATALITIES, INJURIES AND CRASHES (2004) (finding that from 1968-2002 nearly 253,000 avoidable deaths in the United States were attributable to a defined subset of federal vehicle safety standards).

3 Matthew T. Lee, The Ford Pinto Case and the Development of Auto Safety Regulations, 1893-1978, 27 BUS. \& ECON. HIST. 390, 394-95 (1998), available at http://www.thebhc.org/publications/BEHprint/ v027n2/p0390-p0401.pdf ("Although the auto industry did little to encourage public discussion of auto safety issues, it was instrumental in framing this debate. ... [T]he industry 'owned' the power to define the problem of auto safety and fixed political responsibility for deaths on driver behavior and road design rather than car design. . . . The 
vehicle manufacturers "reinforce[ed] certain common sense ideas about traffic safety"- that drivers were responsible for car accidents and that vehicle design could not do much to make serious crashes survivable-"and suppress[ed] others."4 Auto insurers-who bear much of the economic cost of car crashes through a combination of first party and liability insurance-initially joined auto manufacturers in pushing driver education and traffic safety laws over vehicle design standards. Eventually, however, injury epidemiologists convinced the insurers that improved vehicle design promised greater safety gains and cost savings and thus drove a wedge between insurers and manufacturers. ${ }^{5}$ Ultimately, the auto insurance industry played a crucial role in turning the tide against motor vehicle injuries by funding research to develop vehicle safety standards and lobbying to make them law. ${ }^{6}$ Thirdparty payers have powerful incentives to reduce the costs associated with illness, injury, and property damage. They also have powerful influence on policymakers with regard to the law and policy strategies adopted for reducing those costs.

industry's actions . . . effectively marginalized safety critics concerned with vehicle design."), archived at http://perma.cc/Z4ES-5323.

$4 \quad$ Id. at 395.

5 MARTIN Albaum, SAFETy SElls: MARKET FORCES AND REGUlation IN THE DEVELOPMENT OF AIRBAGS 18 (2005), available at http://safetysells.org/contents.html (describing a shift in the auto insurance industry toward seeing "federal auto safety regulation as one way of stemming the inflation in insurance premiums" and a "move away from [insurers'] traditional reluctance to challenge the automotive establishment").

6 About the Institutes, HighWAY SAFETY RESEARCH \& COMMC'NS, http://www.iihs.org/iihs/about-us (describing the history of the Insurance Institute for Highway Safety and injury prevention epidemiologist William Haddon's instrumental role in transforming it into an independent research organization pioneering the use of scientific methods to develop and test interventions to reduce "crash losses" rather than simply preventing crashes by altering driver behavior); DAVID HemenWAY, WHILE WE WERE SLEEPING: SuCCESS STORIES IN INJURY AND VIOLENCE PREVENTION 9-19 (2009) (describing the role of auto insurance companies in supporting injury prevention research and policy change). 
In the health insurance context, underappreciated provisions in the Affordable Care Act ("ACA")7 encourage third-party payers-employers, private health insurers, and public Medicaid programs-to take a more active role in reducing health care costs by conditioning the terms of coverage on individuals' compliance with recommended health behaviors aimed at preventing heart disease, stroke, and cancer. Champions of this approach, which I call "personal responsibility for wellness," argue that it could help halt rising health care costs and turn the tide against some of the most pressing public health problems of our time. ${ }^{8}$ Employers exhibit enormous enthusiasm for programs that condition financial rewards and penalties (typically in the form of premium discounts or surcharges or differential cost-sharing through deductibles, co-pays, and co-insurance) on individual participation in wellness programs ranging from health screenings to weight loss counseling. ${ }^{9}$ The proportion of employers offering incentivebased programs has increased dramatically over the past few years. ${ }^{10}$ An annual survey of employers with 1000 or more employees indicates that in 2014 nearly $70 \%$ of them

7 Patient Protection and Affordable Care Act, Pub. L. No. 111-148, 124 Stat. 119-1025 (2010).

8 See, e.g., Katherine Baicker et al., Workplace Wellness Programs Can Generate Savings, 29 HEALTH AFF. 304 (2010) (metaanalysis concluding that workplace wellness programs improve health outcomes and reduce health care costs). Chronic conditions (including chronic pain and mental health disorders as well as heart disease, stroke, and cancer) account for about $75 \%$ of health-care costs in the United States. See CTRS. For Disease ConTrol AND Prevention, The Power to Prevent, The CALl to Control: At A Glance 2 (2009), available at http://www.cdc.gov/chronicdisease/resources/publications/ aag/pdf/chronic.pdf, archived at http://perma.cc/S8W8-Z2TC.

9 The prevalence of wellness programs and their design features (including among smaller employers) are discussed further in Part II.A, infra.

10 See TOWERS WATSON/NATIONAL BUSINESS GROUP ON HEALTH, 2014 EMPloyer SuRVEy ON PURCHASING VAlUE IN Health CARE (2014), available at $\mathrm{http}: / /$ www.towerswatson.com/en-US/Insights/IC-Types/SurveyResearch-Results/2014/03/towers-watson-nbgh-employer-survey-onpurchasing-value-in-health-care. [hereinafter "TOWERS WATSON SURVEY"], archived at http://perma.cc/XK68-FT5L?type=pdf. 
offered healthy behavior incentives. ${ }^{11}$ Many employers are shifting away from incentives for participation alone toward incentives tied to the maintenance of particular health metrics or the attainment of particular results in a defined time period. As of $2014,42 \%$ had adopted incentives tied directly to smoking status with an additional $16 \%$ planning to do so in 2015.12 Twenty-two percent used incentives tied to biometrics like weight and cholesterol, with an additional $24 \%$ reporting that they planned to do so in $2015 .{ }^{13}$ At the same time, Medicaid programs in politically conservative states have been experimenting with applying the corporate wellness program model to their Medicaid populations, with mixed results. ${ }^{14}$

Critics of incentive-based personal responsibility for wellness programs are concerned that these programs may simply shift health care costs from third-party payers to individuals without resulting in better health outcomes. ${ }^{15}$ Given that there is often a lapse of decades between behaviors like tobacco use, unhealthy eating, or physical inactivity and the health care costs associated with them, ${ }^{16}$

$\begin{array}{ll}11 & I d . \text { at } 23 . \\ 12 & I d . \text { at } 22 . \\ 13 & I d .\end{array}$

14 See Karen J. Blumenthal et al., Medicaid Incentive Programs to Encourage Healthy Behavior Show Mixed Results to Date and Should be Studied and Improved, 32 HEALTH AFF. 497, 499 (2013). The prevalence and design of Medicaid personal responsibility for wellness reforms is discussed further in Part II.E, infra.

15 John DiNardo et. al., Toward a Scientific Approach to Workplace Wellness: $A$ Response to Ron Goetzel, HEALTH AFFAIRS BLOG (July 1, 2013), http://healthaffairs.org/blog/2013/07/01/toward-a-scientificapproach-to-workplace-wellness-a-response-to-ron-goetzel/, archived at http://perma.cc/Z2EX-D87W.

${ }_{16}$ See, e.g., William Weiss, Cigarette Smoking and Lung Cancer Trends: $A$ Light at the End of the Tunnel?, 111 CHEST 1414, 1416 (1997) (suggesting "an average latency interval between onset of smoking and lung cancer diagnosis of close to 50 years"), available at http://journal.publications.chestnet.org/data/Journals/CHEST/21747/141 4.pdf, archived at http://perma.cc/S3X7-WXGV; J.G. Eriksson et. al., Catch-up Growth in Childhood and Death From Coronary Heart Disease: Longitudinal Study, 318 BRIT. MED. J. 427 (1999), available at http://www.ncbi.nlm.nih.gov/pmc/articles/PMC27731/pdf/427.pdf 
and given that Americans frequently move from one form of health care coverage to another over the course of a lifetime, ${ }^{17}$ third-party payers' interests may not be entirely well aligned with sound prevention policy. Personal responsibility for wellness reforms aims to incentivize individual behavior change without necessarily facilitating it through environmental changes. By creating conditions hostile to those who are unhealthy (or are perceived as unhealthy due to their weight or other factors), reforms have the potential to encourage "lemon dropping" by driving unhealthy employees away from wellness-oriented employers while directly shifting costs to those who remain, in the form of higher premiums, co-pays and co-insurance. This approach threatens to undermine the ACA's broader goal of promoting access to health care without regard to health status or risk factors.

Elsewhere, I have argued that personal responsibility reforms reflect cultural biases that exaggerate the extent to which ill health is attributable to the personal failings of unhealthy individuals and that they serve as a political distraction from less punitive measures aimed at making our communities, workplaces, schools, and marketplaces

(linking death from heart disease in later adulthood to prenatal and childhood nutrition); Olli T. Raitakari et al., Associations Between Physical Activity and Risk Factors for Coronary Heart Disease: the Cardiovascular Risk in Young Finns Study, 29 MED. \& SCI. SPORTS \& EXERCISE 1055 (1997), available at http://www.ncbi.nlm.nih.gov/ pubmed/9268963 (associating physical activity in childhood and young adulthood with blood cholesterol levels and risk of premature coronary heart disease during middle age).

17 Erika C. Ziller et. al., Patterns of Individual Health Insurance Coverage, 1996-2000, 23 HEALTH AFF. 6, 210 (2004), available at http://content.healthaffairs.org/content/23/6/210.full\#R14 (describing high volatility in enrollment and disenrollment in the individual insurance market); ROBERT SEIFERT \& AMANDA LITTELL-CLARK, MASS.

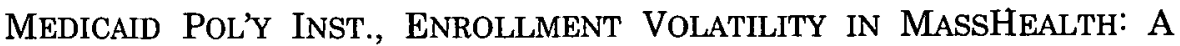
PROGRESS REPORT (2013), available at http://hluecrossmafoundation.org/sites/default/files/download/publication/ Enrollment_Volatility_in_MassHealth_FINAL.pdf (describing high volatility in state Medicaid enrollment). 
more conducive to healthy living. ${ }^{18}$ Here, I assess ongoing agency implementation of the ACA's personal responsibility for wellness reforms and find cause for hope.

This Article describes and assesses ongoing federal agency implementation of ACA personal responsibility for wellness provisions, including the 2013 Workplace Wellness Programs Study; the 2013 Incentives for Nondiscriminatory Wellness Programs in Group Health Plans Final Rule; the Individual Insurance Wellness Program Demonstration Project; the Small Business Workplace Wellness Grant Program; and the Medicaid Incentives for Prevention of Chronic Diseases Grant Program. The Article proceeds in Part I by situating the personal responsibility for wellness approach within the broader federal health law and policy landscape. In Part II, I describe the personal responsibility for wellness provisions included in the ACA and the current state of agency implementation with regard to each. I argue that in implementing these provisions, the Department of Health and Human Services ("DHHS") appears to be taking an appropriately skeptical stance toward personal responsibility for wellness measures that use rewards and penalties to encourage, but not necessarily facilitate, healthier behavior. I conclude by arguing that recent agency actions are a step in the right direction, but continued vigilance is necessary to ensure that third-party payers do not use wellness reforms to undermine the ACA's goals with respect to health care access and disease prevention. I also suggest that public health advocates should continue to seek the support of third-party payers in their efforts to transform our workplaces, communities, schools, and marketplaces to make them more conducive to healthy living.

18 Lindsay F. Wiley, Shame, Blame, and the Emerging Law of Obesity Control, 47 U.C. DAVIS L. REV. 121 (2013) [hereinafter Wiley, Shame]. 


\section{PERSONAL RESPONSIBILITY FOR WELLNESS IN THE FEDERAL HEALTH LAW LANDSCAPE}

After a hard fought political battle, followed by Supreme Court litigation that left its own marks, the United States health care system is in the midst of a challenging transformation. We are shifting toward a far more collective approach to health care financing, while maintaining the basic configuration of our fragmentary health care delivery and financing system. The ACA is expanding Medicaid eligibility beyond the specific categories covered under previous law. ${ }^{19}$ In states that choose to accept the expansion (the Supreme Court's ruling made it truly optional ${ }^{20}$ ), all individuals living below $138 \%$ of the federal poverty level are now eligible, including childless, non-disabled adults. ${ }^{21}$ The Health Insurance Portability and Affordability Act of 1996 ("HIPAA") and the ACA sharply restrict the ability of private health insurance plans to manage and segment risk through individually-focused underwriting. ${ }^{22}$ To make these reforms more feasible and palatable for insurers, the ACA mandates the purchase of private insurance for virtually all individuals who can afford it and who are not otherwise covered. ${ }^{23}$ The threat of a tax penalty ${ }^{24}$ and the availability of financial assistance for lower- and middle-class individuals and families ${ }^{25}$ encourage healthy people to purchase insurance now, rather

19 Patient Protection and Affordable Care Act, Pub. L. No. 111-148, $\S 2001,124$ Stat. 119-1025 (2010).

20 Constance MacIntosh, The Role of Law in Ameliorating Global Inequalities in Indigenous Peoples' Health, 41 J.L. MED. \& ETHICS 77 (2013).

21 Sidney D. Watson, Embracing Justice Roberts' "New Medicaid", 6 ST. LOUIS U. J. HEALTH L. \& POL'Y 247 (2013).

22 See infra Part I.A.1.

2326 U.S.C. $\S 5000 \mathrm{~A}(\mathrm{a})$ (the minimum essential coverage requirement).

2426 U.S.C. $\$ 5000 \mathrm{~A}(\mathrm{~b})$ (the shared responsibility payment).

2526 U.S.C. $\S 36 \mathrm{~B}$ (premium assistance tax credits); 42 U.S.C. $\S$ 18071 (cost-sharing reduction payments). 
than waiting to take advantage of the guaranteed issue ${ }^{26}$ and community rating ${ }^{27}$ protections. Taken together, these reforms effectively subsidize intensive health care consumers at the expense of healthier, less intensive health care consumers, while also protecting those who are perceived as likely to become intensive health care consumers in the future. ${ }^{28}$

Along with increased public responsibility for health care financing comes renewed interest in public responsibility for "upstream" prevention of disease and injury as a strategy for reducing health care costs and improving the public's health and wellbeing. Justice Scalia famously warned that if the government can force people to buy health insurance, there is nothing to stop it from forcing them to buy broccoli as well. ${ }^{29}$ So far, no one has seriously proposed an "eat your vegetables" mandate, but state and local governments are pursuing a wide range of strategies to make healthy choices easier and unhealthy choices harder, including subsidization of fresh produce, taxation of harmful products, zoning and licensing rules aimed at shifting the balance between healthy and unhealthy retail food establishments, and rules governing portion sizes. ${ }^{30}$ The ACA itself includes

2642 U.S.C. $\$ 300 \mathrm{gg}-1$ (guaranteed issue and renewability requirements for health plans).

2742 U.S.C. $\$ \S 300 \mathrm{gg}, 300 \mathrm{gg}-4$ (restricting discriminatory premium rates and prohibiting other forms of discrimination based on health status).

28 Subsidy of the unhealthy by the healthy is a feature of every health care system in the world. The means by which that subsidy is achieved are simply more or less hidden. The ACA makes subsidies more visible, but they were always there, including in the form of padded prices charged to patients with private insurance and out-ofpocket payers to help cover the costs of uncompensated care provided (often inefficiently through the emergency room) to the uninsured.

29 James B. Stewart, How Broccoli Landed on Supreme Court Menu, N.Y. TIMES (June 13, 2012), http://www.nytimes.com/2012/06/14/business/ how-broccoli-became-a-symbol-in-the-health-care-debate.html?_r=0, archived at http://perma.cc/V4QQ-EDY9.

30 See Lindsay F. Wiley, Manel Kappagoda \& Anne Pearson, Public Health Law: Non-Communicable Disease Prevention, in THE OXFORD HANDBOOK OF U.S. HEALTH LAW (Glenn Gohen et al. eds.) 
a federal excise tax on tanning bed services, ${ }^{31}$ a calorie labeling mandate for restaurant menu items, ${ }^{32}$ regulations to facilitate breastfeeding, ${ }^{33}$ and grants to fund other community-level prevention strategies. ${ }^{34}$

Within the context of this broad movement toward greater collective responsibility for health, there is considerable push-back. "Personal responsibility" for health (and financial security, education, and many other aspects of life) has long been a conservative mantra. ${ }^{35}$ It is also used quite cynically - and successfully - by industries that market harmful products (guns, unsafe vehicles, tobacco, alcohol, fast food, and sugary drinks) in their efforts to avoid regulation. ${ }^{36}$ More recently, it is being used by thirdparty payers to blunt the impact of health care reform. Less well-known provisions of the ACA promote personal responsibility for wellness through regulatory exceptions and grant programs aimed at employers, private health plans, and state Medicaid programs. Through these provisions, "the health reform law pays obeisance to the notion that individuals bear responsibility for their own health but can be guided through a system of rewards and penalties to make the 'right' choices." 37

(forthcoming 2014) (describing the public health law toolkit for influencing health behaviors through environmental changes).

3126 U.S.C. $\$ 5000 \mathrm{~B}$ ( $10 \%$ excise tax on tanning bed services).

$32 \quad 21$ U.S.C. $\$ 343(\mathrm{q})(5)(\mathrm{H})$ (requiring restaurants to disclose calorie counts on menus).

$33 \quad 29$ U.S.C. $\$ 207(\mathrm{r})(1)$ (requiring employers to provide adequate break time and facilities for nursing mothers).

$34 \quad 42$ USC $\S 300 \mathrm{u}-13$ (community transformation grants).

35 See Lindsay F. Wiley et al., Who's Your Nanny? Choice, Paternalism and Public Health in the Age of Personal Responsibility, 41 J.L. MED. \& ETHICS S88 (2013).

36 Id. at $\mathrm{S} 89$.

37 Janet L. Dolgin \& Katherine R. Dieterich, Weighing Status: Obesity, Class, and Health Reform, 89 OR. L. REv. 1113, 1134 (2011). 
A. Personal Responsibility for Wellness: Conditioning Financial Incentives on Medical Compliance, Lifestyle Compliance, and Biometrics

The ACA personal responsibility for wellness provisions were adopted at a time of surging scientific and political interest in the use of financial incentives to encourage healthier behaviors. Personal responsibility incentives can be aimed at influencing "medical compliance" behaviors, such as reporting on time for scheduled medical appointments, taking medications as prescribed, and submitting to recommended vaccinations and screening tests. ${ }^{38}$ They can also be aimed at influencing "lifestyle compliance"-including behaviors like tobacco use, diet, and exercise. More controversially, incentives can be tied to the achievement or maintenance of biometrics (such as weight, body mass index, blood pressure, cholesterol, or blood glucose) within specified ranges. This approach effectively treats an individual's health status as a proxy for behavior or lifestyle choices. ${ }^{39}$

38 See Soeren Mattke eT AL., WorkPlace Wellness Programs STUDY: FINAL REPORT xiii (2013) [hereinafter RAND REPORT], available at http://www.rand.org/content/dam/rand/pubs/research_reports/RR200/ RR254/RAND_RR254.pdf, archived at http://perma.cc/Y6QM-T26E.

39 Although healthier eating and physical activity are recommended to prevent and manage obesity, high blood pressure, high cholesterol, and high blood glucose, the characterization of these biometrics as the product of lifestyle choices alone is far from accurate. See, e.g., J.J. Hottenga et. al., Heritability and Stability of Resting Blood Pressure, 8 TwIN RES. HUM. GENETICS 499 (2005) (reviewing twin studies and finding that between $34 \%$ and $67 \%$ of variation in blood pressure from person to person is explained by genetic factors); Cathy Elks, Variability in the Heritability of Body Mass Index: A Systematic Review and Meta-regression, 14 OBESITY REVS. 872 (2013) (reviewing twin studies finding between $47 \%$ and $90 \%$ of variation in adult body mass index from person to person is explained by genetic factors); Daphna Weissglas-Volkov \& Päivi Pajukanta, Genetic Causes of High and Low Serum HDL-Cholesterol, 51 J. LIPID RES. 2032 (2010) (noting estimates that between $40 \%$ and $60 \%$ of variation in HDL cholesterol from person to person is explained by genetic factors), available at http://www.jlr.org/content/51/8/2032; Annemarie Simonis-Bik et al., Heritability of $\mathrm{HbAlc}$ and Fasting Blood Glucose in Different 
Some experimental approaches have rewarded compliance with small, one-time incentives: a few dollars, a voucher or gift card, or participation in lotteries for the same. Studies suggest that these approaches work best when targeted at compliance with a simple requirement (such as showing up for the third shot in a series of vaccinations, taking a dose of tuberculosis medication under observation, or reporting for a post-natal doctor's appointment), but are considerably less effective at inducing more complex forms of compliance (such as eating a healthy diet, engaging in physical activity on a regular basis, or quitting smoking). 40 Other experimental approaches have rewarded compliance with larger financial rewards that are doled out more gradually. But even long-term programs with incremental incentives have thus far been associated with only small and temporary effects on weight or smoking cessation. ${ }^{41}$ Participants who lose weight tend to regain the weight (and then some). ${ }^{42}$ And former smokers who quit

Measurement Settings, 11 TwIN RES. HUM. GeNETICS 567 (2008) (twin study finding that $75 \%$ of variation in glycated hemoglobin from person to person is explained by genetic factors).

40 See RAND Report, supra note 38, at 76, 92; Adam Oliver \& Lawrence D. Brown, Politics of Prevention: A Consideration of User Financial Incentives to Address Health Inequalities, 37 J. HEALTH POL. POL’Y \& L. 201 (2012).

41 See Jill R. Horwitz et al., Wellness Incentives in the Workplace: Cost Savings Through Cost Shifting to Unhealthy Workers, 32 HEALTH AFF. 468, 471(2013) ("Four comprehensive weight loss reviews show little significant loss-particularly over longer periods of time, such as twelve months. For example, a review of long-term, multicomponent weight management programs identified twelve trials, four of which included incentives. The review's conclusion: Incentive-based interventions promoted weight loss, but participants tended to regain the weight.").

42 Id. at 471 ("A meta-analysis of seven trials with follow-up periods of at least twelve months found that financial incentives were associated with a weighted mean loss of 0.88 pound at twelve months and 1.5 pounds at eighteen months, and a weighted mean gain of 2.42 pounds at thirty months, although none of the results were [statistically] significant."). 
after receiving incentives are more likely to relapse than those who quit without incentives. ${ }^{43}$

The terms on which health care coverage is provided are complex and multi-faceted, creating numerous opportunities for the application of small, one-time incentives as well as larger, long-term rewards aimed at medical and lifestyle compliance, as well as maintenance or achievement of particular biometrics. Encouraged by federal regulatory exemptions, waivers, and funding, third-party payers are experimenting with the use of premiums, deductibles, copays, co-insurance, provider networks, and benefits to create incentives for various forms of compliance. In Part II, I will describe current federal programs in detail.

\section{B. Types of Health-care Coverage and Federal Regulation to Ensure Access}

To appreciate how the ACA personal responsibility for wellness provisions operate, one must understand the basics of how people get health-care coverage and how each type of coverage is regulated at the federal level to promote more universal health-care access. Before I turn to detailed description of the ACA's personal responsibility for wellness provisions, I need to describe the general types of healthcare coverage affected by these provisions-private group health plans, private individual-market health insurance, and Medicaid-and the basic contours of access-focused regulation with respect to each. This section provides general background that readers familiar with HIPAA's portability provisions, the ACA's private insurance reforms, and federal Medicaid law may wish to skip.

$43 \quad I d$. at 471 ("In one study, all participants received $\$ 45$ for each interview and blood draw (up to a total of $\$ 180$ ), and incentive group members received $\$ 750$ for smoking cessation, confirmed by cotinine testing-that is, testing for a chemical found in cigarette smoke. After six months, $9.4 \%$ of the incentive group remained non-smoking, compared to $3.6 \%$ of the control group. However, relapse rates six months after the incentives ended were significantly higher for the incentive group."). 


\section{Private Health Insurance}

The majority of Americans under age sixty-five are covered by private health plans. ${ }^{44}$ Federal (and state) regulation of private health care coverage is organized around the three main segments of the private marketlarge-group, small-group and individual/non-group plansbased on the unique market forces affecting each. Most private health insurance is offered as a benefit of employment. ${ }^{45}$ Most of these plans cover large groups, allowing them to reduce actuarial risk by pooling large numbers of employees, which makes medical losses more predictable. ${ }^{46}$ Small employers are less likely to offer health insurance, though many do in spite of the higher per-worker costs. ${ }^{47}$ These small-group plans are more expensive because smaller groups have less bargaining power, higher per-worker overhead costs, and smaller risk pools. ${ }^{48}$ Both large-group and small-group plans benefit from the "healthy worker" effect (for a variety of reasons, people who work generally have lower health-care costs than those who do not). ${ }^{49}$ Individual, or "non-group" health plans that are not tied to employment make up a very small segment of the market. ${ }^{50}$ The individual market is an important one, however, because it is the only option for individuals who do not have insurance through their employment and do not

44 Health Insurance Coverage for Adults 19-64, HENRY J. KAISER FouND., http://kff.org/other/state-indicator/adults-19-64/ (last visited Apr. 24, 2014).

45 Id.

46 Consumer Guide to Group Health Insurance, NAT'L ASS'N OF HEALTH UNDERWRITERS, http://www.nahu.org/consumer/ GroupInsurance.cfm (last visited Apr. 24, 2014) [hereinafter CGGHI], archived at http://perma.cc/3C8L-XK2B.

47 See Paul B Ginsburg et al., Tracking Small-firm Coverage, 1989 1996, 17 HEALTH AFF. 167 (1998).

48 CGGHI, supra note 46.

49 See, e.g., A.J. McMichael, Standardized Mortality Ratios and the "Healthy Worker Effect": Scratching Beneath the Surface, $18 \mathrm{~J}$. OCCUPATIONAL MED. 165 (1976).

50 DELOITTE, THE IMPACT OF HEALTH REFORM ON THE ON THE INDIVIDUAL INSURANCE MARKET: A STRATEGIC ASSESSMENT (2011). 
qualify for public programs like Medicare and Medicaid.51 It is also a particularly problematic market because less healthy individuals (who anticipate that they will need to consume a lot of health care) tend to be overrepresented in the individual market and individual market insurers are unable to spread actuarial risk across the healthier, larger pools that employment-based plans enjoy. ${ }^{52}$

Unlike home, auto, or life insurers, health plans are prohibited from engaging in the most basic forms of riskbased underwriting. ${ }^{53}$ The main tools employed by insurers to differentiate and manage risks (denying coverage to highrisk applicants, charging them higher premiums, and imposing less favorable cost-sharing or coverage exclusions on them) are now prohibited or greatly restricted by federal law. The ACA's "guaranteed issue" provision requires that private health insurers offer coverage to all comers, regardless of health status or related factors. ${ }^{54}$ "Community rating" provisions in the ACA sharply limit insurers' ability to manage financial risk by charging higher rates to individuals who are likely to have greater health-care needs. ${ }^{55}$ And bans on exclusions for treatment of preexisting conditions mean that insurers must cover conditions that are present at the time of enrollment even if they are certain to result in extensive payment of benefits by the insurer. ${ }^{56}$ For large employment-based group plans, larger risk pools and the healthy worker phenomenon make guaranteed issue and community rating quite feasible. Indeed, most group plans already followed these practices before they were required to do so by the Health Insurance

$51 \quad I d$.

$52 \quad I d$.

53 Wendy K. Mariner, Health Reform: What's Insurance Got to Do with It?, 36 AM. J.L. \& MED. 436 (2010).

54 See 42 U.S.C. $\$ 300 \mathrm{gg}-4(\mathrm{a})$ (guaranteed issue and renewability).

5542 U.S.C. $\S 300 \mathrm{gg}-4(\mathrm{~b})$ (prohibiting discriminatory premium rates).

$56 \quad 42$ U.S.C. $\$ 300$ gg-3 (prohibiting pre-existing conditions exclusionary clauses and other forms of discrimination based on health status). 
Portability and Accountability Act of 1996 ("HIPAA"). 57 But the ACA's extension of these regulations to the individual market in 2014 and its expanded ban on pre-existing conditions exclusions for all plans pose new challenges.

Particularly in light of their reduced ability to manage risk using the tools of traditional insurance, private employers (whether large or small) and private insurers are highly motivated to reduce health-care costs through other means. On average, employers who offer health insurance coverage as a benefit of employment pay about $\$ 11,000$ per year for family coverage and $\$ 4500$ per year for single coverage. ${ }^{58}$ Insurers are under pressure from consumers to keep premium increases to a minimum even as health-care costs continue to rise at a rate that far outstrips regular inflation. Premium increases in the small-group and individual markets are monitored by federal and state regulators. .9 $^{2}$ Large hikes are also routinely reported on by the media-generating bad press for health plans and "Obamacare" reforms alike.

\section{Public Programs}

Nearly one-quarter of the U.S. population is covered by Medicaid or the Children's Health Insurance Program ("CHIP"), a federally block-granted adjunct to Medicaid.60

57 See Health Insurance Portability and Accountability Act, Pub. L. 104-191, 110 Stat. 1936 (1996).

58 See KaISER Family Found. \& Health Research \& Educ. Trust, Employer Health Benefits: ANNuAl SuRvey 64 (2011), $\mathrm{http}: / /$ kaiserfamilyfoundation.files.wordpress.com/2013/04/8225.pdf.

$59 \quad$ See, e.g., 42 USC § 300gg-94 (2014) (providing for premium rate reviews); National Conference of State Legislatures, State Approval of Health Insurance Rate Increases, http://www.ncsl.org/research/health/ health-insurance-rate-approval-disapproval.aspx (last updated February 2014) (surveying state laws regarding rate increase review and approval), archived at http://perma.cc/4FBY-CPTS?type=image.

60 Medicaid Enrollment as a Percent of Total Population, 2010, HENRY J. KAISER FAMILY FOUND., http://kff.org/medicaid/stateindicator/medicaid-enrollment-as-a-of-pop/ (indicating Medicaid enrollment as of 2010 as $21 \%$ of the total U.S. population); DIANE ROWLAND ET AL., MEDICAID AND CHIP PAYMENT AND ACCESS COMM'N, 
Unlike Medicare (a program for the elderly and disabled that is entirely federally run), ${ }^{61}$ Medicaid is funded and administered jointly by the federal government and the states. As such, it is governed by relatively broad federal guidelines that give states considerable leeway to determine the exact contours of eligibility and benefits. ${ }^{62}$ Even greater flexibility is afforded through a waiver process whereby a state may petition the Centers for Medicare and Medicaid Services to waive particular regulations as part of a research or demonstration project. Section 1115 of the Social Security Act gives the HHS Secretary authority to waive regulations with respect to approved experimental, pilot, or demonstration projects. ${ }^{63}$ With a section 1115 waiver, a state may develop and implement new approaches to coverage that would otherwise by prohibited under federal law. These demonstration projects are typically approved for a five-year term, renewable for an additional three years. Demonstration projects must be budgetneutral with regard to federal expenditures, ${ }^{64}$ but federal grant programs occasionally make additional funds available to test new approaches.

The states have an enormous interest in controlling health-care costs associated with their Medicaid programs. Medicaid spending accounted for nearly one-quarter of all

REPORT TO THE CONGRESS ON MEDICAID AND CHIP 5 (2013), available at https://docs.google.com/viewer?a=v\&pid=sites\&srcid=bWFjcGFjLmdvdn xtYWNwYWN8Z3g6NWE3MTM2NWU4NjhhNDVmYQ (providing enrollment numbers for 2013 that equate to $23 \%$ of the total U.S. population).

61 Medicare has not been the focus of ACA personal responsibility for wellness provisions and thus is not discussed further in this article.

62 Nicole Huberfeld, Federalizing Medicaid, 14 U. PA. J. CoNST. L. 431, 447-48 (2011)

$63 \quad$ Id.

64 Section 1115 Demonstrations, MEDICAD.GOV, http://www.medicaid. gov/Medicaid-CHIP-Program-Information/By-Topics/Waivers/1115/Section1115-Demonstrations.html (last visited Apr. 24, 2014), archived at http://perma.cc/9NV4-C8U6. 
state expenditures in 2013.65 Smoking among Medicaid recipients is $53 \%$ more prevalent than among the population as a whole, ${ }^{66}$ and annual medical costs for smokers are significantly higher than those for nonsmokers. ${ }^{67}$ Although information about diabetes prevalence among the Medicaid population is not available, 68 commentators have suggested that " $[t]$ he high prevalence of diabetes among minority populations coupled with the high percentage of minority Medicaid beneficiaries suggests that a disproportionate number of Medicaid beneficiaries suffer from diabetes." 69 And diabetes is a very expensive disease to manage. ${ }^{70}$ Given what is known about the strong links between many health problems and poverty, ${ }^{71}$ it seems

65 NAT'L Ass'N OF STATE Budget OfFicers, StATE ExPENDiture REPORT 2 (2013), available at http://www.nasbo.org/sites/default/ files/State\%20Expenditure\%20Report\%20\%28Fiscal\%202011-2013\&20 Data\%29.pdf, archived at http://perma.cc/E4MW-JPDH.

66 Brian S. Armour et al., State-Level Medicaid Expenditures Attributable to Smoking, 6 PREVEnTING ChRonic DISEASE A84, A84 (2009), available at http://www.cdc.gov/pcd/issues/2009/jul/08_0153.htm, archived at http://perma.cc/9482-B2EB.

67 Maggie Fox, Smoking Employees Cost \$6,000 A Year More, Study Finds, NBC NEws (June 3, 2013, 6:55 PM), http://www.nbcnews.com/health/ smoking-employees-cost-6-000-year-more-study-finds-6C10182631, archived at http://perma.cc/A7SA-7GUX?type=image.

68 See, e.g., Diabetes Medicare Beneficiaries (Percent), HEALTH INDICATORS WAREHOUSE, http://healthindicators.gov/Indicators/ Diabetes-Medicare-beneficiaries-percent_294/Profile/ClassicData (last visited Apr. 24, 2014) (reporting that more than one-quarter of Medicare beneficiaries have diabetes, but lacking similar information regarding Medicaid beneficiaries), archived at http://perma.cc/4EH6-TYBP.

69 Health Strategy Consultancy \& DUKe UnIV. FUQUA ScH. of Bus., Medicaid Cost Containment and Potential EFFEcts ON DIABETIC BENEFICIARIES 1,6 (2003), available at http://www.avalerehealth.net/research/docs/HSC_Diabetes_White_Pape r_20031021.pdf.

70 Xiaohui Zhuo et al, Lifetime Direct Medical Costs of Treating Type 2 Diabetes and Diabetic Complications, 45 AM. J. Preventative MED. 253 (reporting that diabetics face medication costs up to $\$ 600$ annually, in addition to approximately $\$ 500$ in physicians visits, and $\$ 100-\$ 300$ in self-testing devices), available at http://www.ajpmonline. org/article/S0749-3797(13)00338-3/fulltext.

71 Alyssa Brown, With Poverty Comes Depression, More Than Other Ilnesses, GALLUP (Oct. 30, 2012), http://www.gallup.com/poll/158417/ 
likely that the Medicaid population is generally sicker than the non-Medicaid population.

\section{THE ACA's PERSONAL RESPONSIBILITY FOR WELLNESS PROVISIONS}

The ACA promotes personal responsibility for wellness through five main provisions targeting each of the types of health-care coverage described above. First, the statute mandated that the Secretaries of Health and Human Services, Labor, and Treasury report to Congress on the effectiveness and impact of the workplace wellness programs that are becoming a common feature of largegroup health plans. Second, although the ACA generally prohibits private health plans from discriminating on the basis of health factors, a "wellness program" exception allows group health plans to adopt incentives and penalties tied to the terms of coverage as part of a program of health promotion and disease prevention. Third, the statute directed DHHS to establish a demonstration project whereby individual-market health plans are permitted to adopt wellness programs. Fourth, the ACA authorized a program to subsidize the creation of new workplace wellness programs by small businesses. Fifth, the ACA mandated a grant program for state Medicaid programs experimenting with the use of incentives aimed at chronic disease prevention. In this part, I will examine agency implementation with regard to each of these provisions. Although the statute itself provides fairly detailed parameters for each of these provisions, federal agencies retain significant flexibility to resolve and clarify statutory ambiguities. As described below, agencies appear to be resolving statutory ambiguities in ways that minimize the

poverty-comes $\cdot$ depression-illness.aspx?utm_source $=$ alert\&utm_medium $=$ email\&utm_campaign $=$ syndication\&utm_content $=$ morelink\&utm_term $=$ All \%20Gallup\%20Headlines (finding that more than $30 \%$ of people living in poverty have been diagnosed with depression at some point, compared to only $16 \%$ of people not living in poverty), archived at http://perma.cc/3R79SXPF. 
impact of the personal responsibility for wellness provisions while reinforcing the ACA's broader goals of health care access and disease prevention.

\section{A. The 2013 RAND Report on Workplace Wellness Programs}

In May 2013 (possibly timed to coincide with the promulgation of the wellness program rule discussed below), the non-profit RAND Corporation released a study on workplace wellness programs sponsored by DHHS and the Department of Labor. ${ }^{72}$ The study satisfied an ACA mandate that the Departments report to Congress on the effectiveness of wellness programs and their impact on access to care and affordability of coverage. ${ }^{73}$ Unsurprisingly, the findings of the RAND study did not fully support the hyperbolic 2010 congressional testimony of Safeway executives and others about the benefits of workplace wellness programs. ${ }^{74}$ As described in detail below, the study found that while workplace wellness programs are quite popular with employers, their impact on health-care costs and health outcomes is limited. The RAND survey data and qualitative analysis of five anonymous employer case studies also provide a useful overview of how typical workplace wellness programs operate.

72 RAND REPORT, supra note 38.

73 See 42 U.S.C. $\$ 2801-1$ (2014). The wellness program exception to non-discrimination provisions in the ACA and the Health Insurance Portability and Affordability Act of 1996 is implemented jointly by DHHS and the Department of Labor.

74 See David S. Hilzenrath, Misleading Claims about Safeway Wellness Incentives Shape Health-Care Bill, WASH. Post (Jan. 17, 2010), http://www.washingtonpost.com/wp-dyn/content/article/2010/01/ 15/AR2010011503319.html ("In a legislative debate filled with misconceptions, few rival the myth about Safeway, which has become the poster company for a provision that big employers and insurers covet. The supermarket chain's story shows how the untested claims of interest groups can take on a life of their own and shape national policy."), archived at http://perma.cc/3FK8-M5MF. 


\section{The Prevalence and Design of Workplace Wellness Programs}

Approximately half of U.S. employers with fifty or more employees report that they offer wellness programs. ${ }^{75}$ These programs cover nearly $80 \%$ of employees working for firms with fifty or more employees. ${ }^{76}$ Among employers who report that they do not currently offer a wellness program, more than a quarter express that they are considering offering one in the near future. ${ }^{77}$ Employers typically combine multiple program components with various features. How wellness programs are regulated depends heavily upon the classification of each program component based on its design features. For this reason, it is worth parsing the RAND Report survey data regarding the prevalence of various design features in some detail.

Some workplace wellness program components, which I will refer to as "employer responsibility" programs, are aimed at making the worksite a healthier environment in ways that "make the healthy choice the easy choice"78 for employees. For example, half of all employers with fifty or more employees report that they offer on-site flu vaccination services. ${ }^{79}$ Forty percent say they offer free or subsidized gym memberships or on-site facilities.80 And some employers have taken steps to ensure the availability of healthy food and beverage options in their cafeterias, vending machines, or at meetings. ${ }^{81}$ For example, one of the five anonymous case study employers described in the RAND study (RAND Employer B) reports that it coordinates with a local farmer to sell fresh produce to

75 See RAND Report, supra note 38 , at 18 . As noted in the introduction, the proportion is significantly higher among employers with 1000 or more employees.

76 Id. at 19.

77 Id. at 21.

78 Id.

79 Id. at 23.

$80 \quad I d$.

81 Id. at 22. 
employees once per week and offers a healthy, low-cost lunch special in the cafeteria. ${ }^{82}$

Most wellness programs, however, include one or more components that place the onus on individual employees to change their behaviors. ${ }^{83}$ I will refer to these generally as "personal responsibility" programs, and will further categorize them into distinct sub-types (see Table 1). These programs typically employ financial rewards or penalties ${ }^{84}$

$82 I d$.

83 Id. at 25 (reporting that $72 \%$ of employer wellness programs include a combination of screening and interventions focused on behavior change).

84 In general, I treat rewards and penalties as interchangeable. See Families USA, Wellness Programs: Evaluating the Promises AND PITFALLS 3-4 (2012) ("The difference between a reward and a penalty in a wellness program can be illusory, because a wellness program reward can result in the exact same negative financial effect on workers as a penalty. To understand this, let's imagine a scenario: An employer decides to offer its workers a wellness program in conjunction with health coverage and wants to vary workers' premiums based on whether they participate in a health assessment and five health coaching classes. . . . The employer can achieve this by implementing either a reward or a penalty program. Option 1: . . The employer sets all employees' premium contributions at $\$ 200$ a month. If workers do not complete the wellness program, they have to pay a premium surcharge of $\$ 50$ a month. . . . Option 2: The employer sets all workers' premium contributions at $\$ 250$ a month, and workers who participate in the wellness program receive a $\$ 50$ per month discount on their premiums as a reward. ... In both Option 1 and Option 2, workers who cannot participate in the wellness program end up paying $\$ 250$ a month in premiums, which is $\$ 50$ more than the workers who do participate."), available at http://familiesusa.org/sites/default/files/product_documents/ Wellness-Programs.pdf, archived at http://perma.cc/7LSS-PHWK. The 2013 Rule explicitly treats penalties and rewards as interchangeable. See 29 C.F.R. $\S 2990.702\left(f^{\prime}\right)(1)(i)$ ("Except where expressly provided otherwise, references in this section to an individual obtaining a reward include both obtaining a reward (such as a discount or rebate of a premium or contribution, a waiver of all or part of a cost-sharing mechanism, an additional benefit, or any financial or other incentive) and avoiding a penalty (such as the absence of a premium surcharge or other financial or nonfinancial disincentive). References in this section to a plan providing a reward include both providing a reward (such as a discount or rebate of a premium or contribution, a waiver of all or part of a cost-sharing mechanism, an additional benefit, or any financial or other incentive) and imposing a penalty (such as a surcharge or other 
to prompt individual compliance with desired behaviors. ${ }^{85}$ They generally begin with a screening component to identify at-risk individuals (often with a financial reward to encourage participation in the screening process). Many employers couple that screening component with an intervention component aimed at urging individuals to change their behavior. In many cases, the employer offers a financial award to those who participate in the intervention component, without regard to results. In some cases, the employer offers a financial reward conditioned upon attainment of particular results (such as a $5 \%$ weight loss). Other programs offer a financial award tied directly to the maintenance or achievement of biomarkers within a certain range (such as blood cholesterol levels or a body mass index within a defined range) or to the absence of certain risk factors (such as tobacco use). Personal responsibility programs might include some aspects that make behavior change easier, for example by hosting health screenings or behavior change programming on-site for employees' convenience, but the primary focus is on encouraging employees (and in some cases their dependents) 86 to take responsibility for their own health.

Individuals who currently have or are at increased risk for disease are identified through screening. About $80 \%$ of employers that offer wellness programs include some kind

financial or nonfinancial disincentive)."). The 2006 Rule also treated rewards and penalties as interchangeable. 29 C.F.R. $\$ 2590.702(f)(2)(i)$ (superseded) ("A reward can be in the form of a discount or rebate of a premium or contribution, a waiver of premium or contribution, a waiver of all or part of a cost-sharing mechanism (such as deductibles, copayments, or coinsurance), the absence of a surcharge, or the value of a benefit that would otherwise not be provided under the plan.") (emphasis added).

85 Of the $51 \%$ of employers in the RAND survey that have instituted workplace wellness programs, nearly $70 \%$ have adopted some kind of financial incentive. Id. at 70.

86 The RAND Report did not focus on this issue, but annual surveys of employers with 1000 or more employees conducted by Towers Watson indicate that about $40 \%$ of very large employers extended financial incentives for wellness to covered spouses in 2014, up from $34 \%$ in 2013. See TOWERS WATSON SURVEY, supra note 10, at 23. 
of screening component. 87 Of those, about 38\% conduct their screening programs solely through Health Risk Assessments ("HRAs"), 88 which typically take the form of a questionnaire to collect self-reported information about risk factors and behaviors, including nutrition, physical activity, smoking, weight, blood pressure, and cholesterol.89 More than two-thirds of employers that offer wellness programs use clinical tests that collect biometric data, such as height, weight, blood pressure, blood glucose, and cholesterol, either alone or in combination with HRAs. ${ }^{90}$ These clinical screenings can be conducted on-site or off-site. Some employers conduct screenings for employees only, while others also screen family members covered by the employerbased health plan.

Some incentive-based wellness programs offer rewards for completion of screening assessments or tests, with no further action required based on the results. The health plan might offer incentives like cash payments or prizes unrelated to the terms of health-plan coverage. For example, RAND Employer C reports that it offers $\$ 50$ for completion of an online health assessment and $\$ 20$ for completion of biometric screening. ${ }^{91}$ Or they might tie the financial incentive directly to the terms of health-plan coverage. ${ }^{92}$ For example, RAND Employer D reports that it offers up to a $\$ 2600$ premium differential to employees who complete health screenings, regardless of the results. ${ }^{93}$ RAND Employer B reports that as part of a one-time pilot program, it offered a $\$ 15$ reduction in co-payments for the

$\begin{array}{ll}87 & I d . \text { at } 27 . \\ 88 & I d . \\ 89 & I d . \text { at } 21 . \\ 90 & I d . \text { at } 27 . \\ 91 & I d . \text { at } 71\end{array}$
programs offer merchandise

92 Thirty-eight percent of employers who offer wellness program incentives use discounts or surcharges to alter the cost of health insurance premiums, while about $3 \%$ alter the terms of cost-sharing arrangements (such as co-pays) as an incentive. Id. at 72 .

$93 \quad I d$. at 71 . 
year as a reward to employees who completed an on-site health screening. ${ }^{94}$

Prior to the implementation of non-discrimination provisions in HIPAA (for group plans) and the ACA (for all plans, including insurers in the individual market), these same kinds of screenings were typically conducted by health insurers as part of the application and underwriting process. ${ }^{95}$ In contrast, workplace wellness screenings may not be used to deny coverage to particular employees or their dependents. ${ }^{96}$ Screening test results may, however, be used by employers and group health plans to impose premium discounts or surcharges based on test results or to direct particular individuals to intervention programs. Even for programs that do not include an interventional component, the hope is that giving individuals information about their risk factors might prompt them to alter their behavior.

Personal responsibility interventions may be focused on medical compliance (more than half of employers that have established wellness programs include disease management interventions aimed at promoting adherence to prescribed treatment regimens ${ }^{97}$ ) or lifestyle compliance (about $77 \%$ of employers offering a wellness program report that they offer lifestyle interventions ${ }^{98}$ ). Among employers offering interventions aimed at promoting lifestyle compliance, nearly $80 \%$ offer nutrition or weight-loss programs, including on-site Weight Watchers ${ }^{\mathrm{TM}}$ group meetings, weight-loss competitions, or individualized counseling provided by outside vendors. ${ }^{99}$ About the same proportion offer smoking-cessation programs of a similar nature, and

$\begin{array}{ll}94 & I d \\ 95 & I d .\end{array}$

96 As described in Part II.B.1, infra, HIPAA prohibited group health plans from discriminating on the basis of health status for the purposes of eligibility.
$97 \quad I d$. at 22.
$98 \quad I d$. at 21.
99 Id. 
about half offer alcohol/drug abuse programs and stress management programs. ${ }^{100}$

Employer survey results indicate that about 24\% of workplace smoking-cessation programs, $25 \%$ of weightmanagement programs, and $28 \%$ of fitness programs offer financial rewards for participation. ${ }^{101}$ Apparently, many of these participation-only incentive programs are what I will refer to as "targeted" (in that they are offered to particular individuals based on risk factors or biometric markers identified via screening), while others are presumably offered to all individuals without regard to risk factors or biometric markers. ${ }^{102}$ For example, an employer might offer an incentive to any individual who attends an on-site monthly seminar providing nutritional education or a weekly on-site exercise program. Or the program (and associated incentive) could be offered only to individuals who are identified as having high blood pressure or being overweight.

A smaller-but growing-percentage of programs offer incentives dependent upon particular risk factors or biometric values. ${ }^{103}$ Some programs offer what I will refer to as "status-dependent" financial incentives. These programs offer rewards to (or impose penalties on) individuals identified through screening as falling within

100 Id.

101 Id. at 90.

102 The RAND survey does not distinguish between targeted and non-targeted participation-only incentives, but survey data regarding the percentage of eligible employees who take advantage of participation-only programs (with eligibility apparently based on health status) indicate that many programs are targeted. See id. at 38.

103 As discussed in the introduction, status and result-based incentives are expanding rapidly among employers with 1000 or more employees. See TOWERS WATSON SURVEY, supra note 10 , at $22-23$ (indicating that among employers with 1000 or more employees $42 \%$ had adopted incentives tied directly to smoking status as of 2014 with an additional $16 \%$ planning to do so in 2015 while $22 \%$ used incentives tied to biometrics like weight and cholesterol in 2014 with an additional $24 \%$ reporting that they planned to do so in 2015). These data did not distinguish among status-dependent, results-dependent, and two-tier programs but probably encompass all three. 
particular parameters. For example, RAND Employer D reports an annual premium differential of up to $\$ 754$ (on top of premium discounts available for mere completion of screenings) based solely on biometric readings and smoking status as assessed during annual onsite clinical screenings. ${ }^{104}$ Similarly, RAND Employer B reports that smokers are restricted to a lower-value health plan coverage option. ${ }^{105}$ In other cases, a reward is not offered immediately upon the determination that an individual's biometrics are within a particular range, but is instead dependent upon results achieved through participation in an interventional program (I will call these "results" dependent"). The RAND survey indicates that $19 \%$ of employers that offer smoking-cessation programs offer financial incentives for actual cessation (which can be measured by self-report or through clinical tests), while $6 \%$ of employers offering fitness programs and $3 \%$ offering weight-management programs offer incentives for attainment of predetermined weight loss or fitness goals. ${ }^{106}$

Finally, some employers use a "two-tier" approach. For example, RAND Employer A reports that it imposes a $\$ 50$ annual insurance premium surcharge for smokers who decline to participate in a smoking-cessation program or

$104 I d$. at 71,84 . Employer D reports that it verifies smoking status through blood tests. Id. at 70 . Cotinine testing detects tobacco use by measuring a metabolite of nicotine. The RAND study indicates that among employers who report that they have adopted clinical screenings (as opposed to self-administered questionnaires) as part of their wellness programs, $12 \%$ screen for tobacco use. Id. at 28 . It is unclear, however, whether this "clinical screening" for tobacco use involves a cotinine test or simply amounts to a health care provider asking the patient about tobacco use. Some employers require prospective employees to submit to a cotinine test as a condition of employment. See A.G. Sulzberger, Hospital Shifts Smoking Bans to Smoker Ban, N.Y. TIMES (Feb. 10, 2011), http://www.nytimes.com/2011/02/11/us/ 11smoking.html?pagewanted=all, archived at http://perma.cc/UR6E$5 \mathrm{NAH}$.

105 Id. There is no reference in the report to whether smokers are permitted to enroll in the higher-value coverage option if they also participate in a cessation program, so I will assume that they are not.

106 Id. at 90. 
make use of smoking-cessation products provided by the employer. RAND Employer C takes a slightly different approach, imposing a surcharge of up to $\$ 600$ on smokers who report that they do not intend to quit smoking. Setting aside the question of whether the surcharge should be characterized as a penalty or the absence of it as a reward, the program can be understood as having two tiers. First, smokers are separated from non-smokers, ${ }^{107}$ with nonsmokers automatically avoiding the surcharge (or obtaining the "reward"). Second, individuals who do smoke are given the opportunity to do something else to avoid the penalty, whether that "something else" is simply certifying that they intend to quit or that they are consuming cessation products offered by the employer, or actually participating in a cessation-counseling program. If they do this "something else," they too will avoid the surcharge. In Table 1, I offer a summary of the various types of wellness programs described in the RAND study and the labels I have assigned to each.

Table 1: Wellness Program Typology Based on Descriptions in the RAND Report

\begin{tabular}{|c|c|}
\hline $\begin{array}{l}\text { Employer } \\
\text { Responsibility } \\
\text { Programs }\end{array}$ & $\begin{array}{l}\text { The employer offers services or } \\
\text { alters the worksite for the benefit of } \\
\text { all employees. E.g., an employer } \\
\text { offers healthy, low-cost meal options } \\
\text { in the cafeteria, provides on-site gym } \\
\text { facilities, or hosts on-site flu } \\
\text { vaccination clinics. }\end{array}$ \\
\hline $\begin{array}{l}\text { Non-targeted } \\
\text { Participation-only } \\
\text { Incentive }\end{array}$ & $\begin{array}{l}\text { The employer offers incentives to } \\
\text { all individuals, without regard to } \\
\text { health status or risk factors, for }\end{array}$ \\
\hline
\end{tabular}

107 The RAND study reports that Employers A and C used selfreport to identify smokers (meaning the individuals were asked to describe their tobacco use). See RAND Report, supra note 38, at 73. 


\begin{tabular}{|c|c|}
\hline Programs & $\begin{array}{l}\text { participation in intervention } \\
\text { programs, without regard to results. } \\
\text { E.g., all employees are offered a } \\
\text { financial incentive for participating in } \\
\text { a health education seminar about } \\
\text { healthy eating. }\end{array}$ \\
\hline $\begin{array}{l}\text { Targeted } \\
\text { Participation-only } \\
\text { Incentive } \\
\text { Programs }\end{array}$ & $\begin{array}{l}\text { The employer designates particular } \\
\text { individuals as eligible for participation } \\
\text { in intervention programs based on } \\
\text { their health status or risk factors and } \\
\text { offers those employees rewards for } \\
\text { participation, without regard to } \\
\text { results. E.g., smokers are offered } \\
\text { financial incentives for participating } \\
\text { in a cessation program. }\end{array}$ \\
\hline $\begin{array}{l}\text { Status-dependent } \\
\text { Incentive } \\
\text { Programs }\end{array}$ & $\begin{array}{l}\text { The employer automatically } \\
\text { applies rewards or penalties based } \\
\text { solely on individuals' health status or } \\
\text { risk factors. E.g., smokers must pay a } \\
\text { premium surcharge; employees with a } \\
\text { body mass index below } 26 \text { are offered } \\
\text { a premium discount. }\end{array}$ \\
\hline $\begin{array}{l}\text { Results-dependent } \\
\text { Incentive } \\
\text { Programs }\end{array}$ & $\begin{array}{l}\text { The employer offers rewards } \\
\text { conditioned on the achievement of } \\
\text { particular results through } \\
\text { intervention programs (or } \\
\text { independently). E.g., participants in a } \\
\text { smoking cessation program are offered } \\
\text { a reduction in their co-payment rate } \\
\text { for remaining tobacco-free for six } \\
\text { months; participants in a weight loss } \\
\text { program are offered a premium } \\
\text { discount for losing } 5 \% \text { of their body } \\
\text { weight. }\end{array}$ \\
\hline
\end{tabular}




\begin{tabular}{|l|l|}
\hline & $\mid$ \\
\hline Two-tier Programs & $\begin{array}{l}\text { The employer divides individuals } \\
\text { into two groups based on health status } \\
\text { or risk factors. Individuals in the } \\
\text { "healthy" group are automatically } \\
\text { given a reward. Those in the } \\
\text { "unhealthy" group are offered the } \\
\text { same reward conditioned upon } \\
\text { participation in an intervention } \\
\text { program or achievement of particular } \\
\text { results. E.g., smokers must pay a } \\
\text { premium surcharge unless they attend } \\
\text { a weekly smoking cessation program; } \\
\text { non-smokers automatically avoid the } \\
\text { surcharge. }\end{array}$ \\
\hline
\end{tabular}

The RAND Report notes that the use and magnitude of financial incentives for wellness is likely to increase over time. Nearly $90 \%$ of employers with 200 or more employees report that they plan to add or strengthen financial incentive programs. ${ }^{108}$ A 2014 survey of employers with 1000 or more employees found that "the use of incentives . . . continues to grow significantly-with more focus on results than mere participation." 109 In spite of the popularity of incentives among employers, the RAND study reports that "wellness program managers [have] mixed feelings about the use of incentives to encourage healthy behaviors," citing interviews conducted with wellness program representatives suggesting that there is a "struggle in the wellness field in general" over the use of financial incentives, as opposed to purely intrinsic, health-focused motivation. 110

108 Id. at 88-89.

109 See TOWERS WATSON SURVEY, supra note 10, at 22.

110 Id. at 82. 


\section{The Impact of Workplace Wellness Programs}

Evaluation of the impact of these programs is limited. Only about half of employers who have wellness programs report that they have evaluated them. ${ }^{111}$ The RAND study's assessment of impact was limited to employer surveys regarding levels of participation in various components, supplemented by a small number of case studies of individual employers for which more detailed data was available. The results indicate that employee participation in wellness programs is not widespread. Where screening components are offered, about half of employees participate in them. ${ }^{112}$ Participation in intervention components is significantly lower. Employers report that only 11\% of eligible employees (with eligibility typically based on risk assessment results via a targeted approach) participated in a weight-loss program while only $7 \%$ of employees who smoke participated in a smoking-cessation program within the last twelve months. ${ }^{113}$

The RAND study also examined more detailed data collected from a very small number of employers by the Care Continuum Alliance ("CCA"), an industry trade group that represents the interests of wellness program vendors and other groups interested in disease management. The CCA data from one large employer suggests that participation in an exercise program is associated with 0.15 additional days per week during which participants exercise for twenty or more minutes, when compared to nonparticipants, with diminishing effects in subsequent years.114 Similar data, also from a single employer, suggests that smoking rates are $30 \%$ lower among participants in a smoking-cessation program than among non-participants. ${ }^{115}$ CCA data from four employers suggests that participation in a weight-loss, nutrition, or

\footnotetext{
111 Id. at 53.

112 Id. at 36 .

113 Id. at 38.

$114 I d$. at 44.

115 Id. at 45.
} 
exercise program is associated with a body mass index reduction of about 0.15 during the year of participation and additional, but diminishing reductions in subsequent years. Overall, the average three-year reduction in body mass index associated with participation corresponds to a weight loss of about one pound. ${ }^{116}$ CCA data from four employers do not indicate a statistically significant reduction in cholesterol.117 The data were insufficient to show a statistically significant reduction in health care costs. The RAND report notes, however, that other studies have demonstrated statistically significant health care cost reductions. For example, a widely reported 2010 metaanalysis suggested that the average return on each dollar invested in workplace wellness programs was about $\$ 3$ in terms of reduction in health care costs and absenteeism. ${ }^{118}$

\section{B. The Group Health Plan Wellness Program Exception}

As described above, some workplace wellness programs take an approach that emphasizes employer responsibility for creating a healthier work environment, while others adopt a personal responsibility approach. Employer responsibility programs have the potential to improve the health of employees without penalizing those who are perceived as unhealthy. On the other hand, personal responsibility programs-especially those that make premium discounts, surcharges, or cost-sharing reductions dependent upon the absence of particular risk factors (like tobacco use) or the maintenance or attainment of "healthy" biometric values (like a body mass index or cholesterol level in a particular range), raise the possibility of bringing prohibited health-status underwriting "in through the back

116 The results were reported in terms of average change in body mass index, corresponding to weight loss of 0.9 pounds for an average woman of 165 pounds and 5'4" or about one pound in the average man of 195 pounds and 5'9". Id. at 47 .

117 Id. at 51.

118 Id. at 62 (citing Katherine Baicker et al., Workplace Wellness Programs Can Generate Savings, 29 HEALTH AFF. 304, 304-11 (2010)). 
door."119

Wellness programs that alter the terms of coverage based on "health status-related factors" (including smoking status, weight, blood pressure, cholesterol, and other medical history) are legally permissible for group health plans only because of an exception to the general rule prohibiting health plans from discriminating on the basis of these factors. ${ }^{20}$ As described below, this exception originated in 1996 with HIPAA $^{121}$ and was fleshed out in regulations promulgated in 2006.122 In 2010, Congress

119 Timothy Jost, Implementing Health Reform: Wellness Programs and Medicaid FAQs, HeALTh AFFairs Blog (Nov. 21, 2012, 4:45 PM), http://healthaffairs.org/blog/2012/11/21/ implementing-health-reform-wellness-programs-and-medicaid-faq, archived at http://perma.cc/HV6D-8DLE.

120 See 29 U.S.C. $§ 1182(\mathrm{~b})(1)$ (2014) ("A group health plan, and a health insurance issuer offering health insurance coverage in connection with a group health plan, may not require any individual (as a condition of enrollment or continued enrollment under the plan) to pay a premium or contribution which is greater than such premium or contribution for a similarly situated individual enrolled in the plan on the basis of any health status-related factor in relation to the individual or to an individual enrolled under the plan as a dependent of the individual."); 42 U.S.C. $\$ 300 \mathrm{gg}-4(\mathrm{~b})(1)$ (applying the same prohibition to "a health insurance issuer offering group or individual health insurance coverage") (emphasis added). Note that although smoking status meets the statutory definition for a health status-related factor, the ACA allows insurers to vary premium rates by a 1.5 to 1 ratio based on smoking status, in a provision independent from the wellness program exception. See 42 U.S.C. $\$ 300 \mathrm{gg}(\mathrm{a})(1)(\mathrm{A})$ (iv). This provision is relevant to interpretation of the 2013 wellness program rule and may help explain why smoking cessation incentives appear to be treated differently from other kinds of status- or results-based incentives under the examples set forth in the rule, as described below.

121 See 29 U.S.C. $§ 1182(\mathrm{~b})(2)(\mathrm{B})$ (2014) (specifying that the prohibition of discrimination on the basis of health status-related factors shall not be construed "to prevent a group health plan, and a health insurance issuer offering group health insurance coverage, from establishing premium discounts or rebates or modifying otherwise applicable copayments or deductibles in return for adherence to programs of health promotion and disease prevention.").

122 See Nondiscrimination and Wellness Programs in Health Coverage in the Group Market; Final Rules, 71 Fed. Reg. 75,014, 75,017-19 (Dec. 13, 2006) (codified at 26 C.F.R. pt. 54, 29 C.F.R. pt. 
imported the wellness program exception from HIPAA into the ACA. ${ }^{123}$ The ACA also incorporates additional language regarding wellness programs from the 2006 Rule. ${ }^{124}$ Regulations interpreting the ACA provisions, released in $2013,{ }^{125}$ indicate that DHHS is now taking a more skeptical stance toward personal responsibility incentives. Compared to the 2006 Rule, which it supersedes, the 2013 Rule resolves statutory ambiguity in favor of subjecting a wider range of programs to more stringent requirements and is thus more likely to ensure that wellness programs are not used as a subterfuge for prohibited health-factor discrimination. ${ }^{126}$

2590, and 45 C.F.R. pt. 146), available at
http://www.dol.gov/ebsa/regs/fedreg/final/2006009557.pdf, archived at http://perma.cc/M7GB-YDET. Although the Federal Register indicated that the provisions relevant to wellness programs would be codified at 45 C.F.R. $\$ 146.121(\mathrm{f})$, in fact the relevant provisions were codified at 29 C.F. R. 2990.702(f) (2007) (superseded). As described below, these provisions were later superseded by the 2013 Rule, which is codified at 29 C.F.R. 2990.702(f) (2014).

123 See 42 U.S.C. $\S 300 \mathrm{gg}-4(\mathrm{~b})(2)$ (B) (2014) (specifying that the prohibition of discrimination on the basis of health status-related factors shall not be construed "to prevent a group health plan, and a health insurance issuer offering group health insurance coverage, from establishing premium discounts or rebates or modifying otherwise applicable copayments or deductibles in return for adherence to programs of health promotion and disease prevention.").

124 See 42 U.S.C. $\S 300 \mathrm{gg}-4(\mathrm{j})(1)(\mathrm{B})$ (2014) (adopting language almost identical to that found in 29 C.F.R. 2990.702(f) (2007) (superseded)); 42 U.S.C. $§ 300 g g-4(j)(2)$ (adopting language almost identical to that found in from 29 C.F.R. 2990.702(f)(1) (2007) (superseded)); 42 U.S.C. $§ 300 g g-4(j)(3)$ (2014) (adopting language very similar to that found in 29 C.F.R. 2990.702(f)(2) (2007) (superseded) but with the important addition of language indicating that the requirements set forth in the statute are not exhaustive, as described below).

125 See Incentives for Nondiscriminatory Wellness Programs in Group Health Plans; Final Rule, 78 Fed. Reg. 33158 (Jun. 3, 2013) (codified at 26 C.F.R. pt. 54, 29 C.F.R. pt. 2990, and 45 C.F.R. pt. 146, 147) available at http://www.gpo.gov/fdsys/pkg/FR-2013-06-03/pdf/201312916.pdf.

126 The 2006 Rule, the ACA, and the 2013 Rule all prohibit the use of wellness programs as a subterfuge for discrimination on the basis of health status-related factors. See 29 C.F.R. $\$ 2990.702(f)(2)(i i)$ (2007) (superseded) 


\section{The Wellness Program Exception in HIPAA}

HIPAA prohibits group plans from discriminating based on health factors for purposes of eligibility or setting premiums or contributions. ${ }^{127}$ "Health factors" are listed in HIPAA as "health status; medical condition, including both physical and mental illnesses; claims experience; receipt of health care; medical history; genetic information; evidence of insurability; and disability." 128 Plans are prohibited from imposing differential rates for particular individuals based on any of these factors. The statute includes a vaguely defined exception to the general non-discrimination rule that allows plans to "establish premium discounts or rebates or modify otherwise applicable copayments or deductibles in return for adherence to programs of health promotion and disease prevention." 229 In 2006, the Departments of Health and Human Services, Treasury, and Labor ${ }^{130}$ jointly issued final regulations delineating the parameters of this exception. ${ }^{131}$

(stating that programs that condition a reward on satisfaction of health status-related standard "must be reasonably designed to promote health or prevent disease" and specifying that this standard is satisfied if a program "has a reasonable chance of improving the health of or preventing disease in participating individuals and is not overly burdensome, is not a subterfuge for discriminating based on a health factor, and is not highly suspect in the method chosen to promote health or prevent disease.") (emphasis added); 42 U.S.C. $\S 300 \mathrm{gg}-4(\mathrm{j})(3)$ (B) (2014) (adopting virtually identical language); 29 C.F.R. $§ 2590.702(\mathrm{f})(3)$ (iii) (2014) (adopting virtually identical language, with the additional provision that determinations regarding the "reasonable design" standard are "based on all the relevant facts and circumstances.").

127 See 29 U.S.C. $§ 1182$ (2014) (prohibiting discrimination against individual health plan participants and beneficiaries based on health status)

128 See 29 U.S.C. $\S 1182(\mathrm{~b})(2)$ (B) (2014). The 2006 Rule further defined "Evidence of insurability" to include: "(i) Conditions arising out of acts of domestic violence; and (ii) Participation in activities such as motorcycling, snowmobiling, all-terrain vehicle riding, horseback riding, skiing, and other similar activities." 29 C.F.R. $§ 2590.702(a)(2)$ (2007) (superseded).

129 See 29 U.S.C. § $1182(\mathrm{~b})(2)(\mathrm{B})(2014)$.

130 HIPAA, like the ACA after it, amended provisions of the Public Health Service Act, the Earned Retirement Income Security Act, and 


\section{The 2006 Wellness Program Rule}

The 2006 Rule distinguished between programs that condition a reward upon satisfaction of "a standard that is related to a health factor" and those that do not.132 For simplicity, I will refer to these as "standard-based" and "nonstandard-based." For non-standard-based programs (and those that do not offer a reward in the form of differential health plan benefits, cost-sharing mechanisms, premiums or contributions for similarly situated individuals), the only restriction imposed by the 2006 Rule was that "participation must be made available to all similarly situated individuals, regardless of health status."133

Wellness programs that do condition a reward (in the form of differential health plan benefits, cost-sharing mechanisms, premiums or contributions for similarly situated individuals) upon satisfaction of a standard related to a health factor were subjected to considerably greater regulation. Five requirements for standard-based programs were set forth in the 2006 Rule: First, the combined reward for achieving all available wellness program standards must not exceed $20 \%$ of the cost of coverage under the plan. Second, the program must be "reasonably designed to promote health or prevent disease." The 2006 Rule specified that this reasonable design requirement would be satisfied if a program "has a

the Internal Revenue Code. Regulations implementing it fall under the purview of all three of these Departments.

131 Nondiscrimination and Wellness Programs in Health Coverage in the Group Market; Final Rules, 71 Fed. Reg. at 75,014 (Dec. 13, 2006) (codified as amended at 26 C.F.R. pt. 54, 29 C.F.R pt. 2590, 45 C.F.R. pt. 146).

13229 C.F.R. $\S 2590.702$ (f) (2007) (superseded).

133 See 29 C.F.R. $\S 2590.702(f)(1)$ (2007) (superseded); 42 U.S.C. $\S$ $300 \mathrm{gg}-4(\mathrm{j})(2)$ (2014) (identical ACA provision). These programs must also comply with employment and insurance laws that prohibit discrimination based on race, age, gender, religious beliefs and observances, and disability. A program that requires attendance at meetings on Saturday mornings, for example, might be deemed to discriminate against members of certain religions. A participation-dependent incentive program that requires particular physical activities might need to be adjusted to accommodate employees with physical disabilities. 
reasonable chance of improving the health of or preventing disease in participating individuals and it is not overly burdensome, is not a subterfuge for discriminating based on a health factor, and is not highly suspect in the method chosen to promote health or prevent disease." 134 Third, enrollees must have the opportunity to qualify for the reward at least once per year. Fourth, the reward must be available to all similarly situated individuals. The 2006 Rule specified that this uniform availability requirement would not be satisfied unless the program allowed "a reasonable alternative standard (or waiver of the otherwise applicable standard) for obtaining the reward for any individual for whom, for that period, it is unreasonably difficult due to a medical condition to satisfy the otherwise applicable standard" or for whom it is "medically inadvisable to attempt to satisfy the otherwise applicable standard." Finally, the plan must disclose the availability of an alternative standard or waiver in all plan materials that describe the terms of the wellness program. ${ }^{135}$ For brevity's sake, I will refer to these as the "five requirements" (see Table 2).

Table 2: Regulation of Wellness Programs under the 2006 Rule

\begin{tabular}{|c|c|}
\hline $\begin{array}{l}\text { Non'standard- } \\
\text { based }\end{array}$ & Standard-based \\
\hline $\begin{array}{l}\text { Participation in the } \\
\text { program must be } \\
\text { made available to } \\
\text { all similarly } \\
\text { situated } \\
\text { individuals. }\end{array}$ & $\begin{array}{l}\text { 1) The total available reward for } \\
\text { all standard-based wellness } \\
\text { programs must not exceed } 20 \% \\
\text { of the cost of coverage under } \\
\text { the plan. } \\
\text { 2) The program must be }\end{array}$ \\
\hline
\end{tabular}

134 See 29 C.F.R. $\S 2590.702(\mathrm{f})$ (2)(ii) (2007) (superseded); 42 U.S.C. $\S 300 \mathrm{gg}-4(\mathrm{j})(3)$ (2014) (nearly identical ACA provision).

135 See 29 C.F.R. $\S 2590.702(\mathfrak{f})(2)$ (2007) (superseded); 42 U.S.C. $\S$ $300 \mathrm{gg}-4(\mathrm{j})(3)$ (2014) (identical ACA provision). 
reasonably designed to promote health or prevent disease. A program satisfies this standard if it has a reasonable chance of improving the health of or preventing disease in participating individuals and it is not overly burdensome, is not a subterfuge for discriminating based on a health factor, and is not highly suspect in the method chosen to promote health or prevent disease.

3) Eligible individuals must be given the opportunity to qualify for the reward at least once per year.

4) The reward must be available to all similarly situated individuals. To satisfy this requirement, the program must allow a reasonable alternative standard (or waiver of otherwise applicable standard) for any individual for whom is its unreasonably difficult due to a medical condition to satisfy or medically inadvisable to attempt to satisfy the otherwise applicable standard.

5) The availability of a reasonable alternative standard or waiver (as set forth in requirement four) must be disclosed in plan materials describing the wellness program. 
The test for determining whether a program would be regulated as standard-based was not fully fleshed out in the 2006 Rule. Some types of programs described in the RAND study are easily classified as non-standard-based: Employer responsibility programs (like RAND Employer B's healthy, low-cost lunch special in the cafeteria) enhance the work environment for all employees without offering financial rewards to anyone in particular and therefore would not be subject to the five requirements. ${ }^{136}$ Programs offering incentives for participation in a health screening without regard to the results (like RAND Employer D's premium differential for health screening participation) would also not be subject to the five requirements because they do not distinguish among individuals based on health factors in any way. Personal responsibility programs that provide incentives for participation in intervention programs (without regard to the results) and are nontargeted (in that they are offered to all individuals without regard to biometrics or risk factors) would also be in the clear. ${ }^{137}$ Although these programs typically do relate to behaviors (like diet or exercise) that are associated with health, they do not adopt a particular health-related

136 Among the examples of programs that do not condition a reward on a standard related to health status provided in the 2006 Rule are three that clearly describe "employer responsibility" programs. See 29 C.F.R. § 2590.702(f)(1)(i) (2007) (superseded) ("A program that reimburses all or part of the cost for memberships in a fitness center."); 29 C.F.R. § 2590.702(f)(1)(iii) (2007) (superseded) ("A program that encourages preventive care through the waiver of the copayment or deductible requirement under a group health plan for the costs of, for example, prenatal care or well-baby visits."); 29 C.F.R. § $2590.702(\mathrm{f})(1)(\mathrm{iv})$ (2007) (superseded) ("A program that reimburses employees for the costs smoking cessation programs without regard to whether the employee quits smoking.").

137 Among the examples of programs that do not condition a reward on a standard related to health status provided in the 2006 Rule, are two that seem to describe non-targeted participation-dependent programs. 29 C.F.R. $\S 2590.702(\mathrm{f})(1)(\mathrm{ii})$ (2007) (superseded) ("A diagnostic testing program that provides a reward for participation and does not base any part of the reward on outcomes."); 29 C.F.R. $§ 2590.702(\mathrm{f})(1)(\mathrm{v})$ (2007) (superseded) ("A program that provides a reward to employees for attending a monthly health education seminar."). 
standard beyond mere participation. As non-targeted participation-only programs, they do not distinguish among individuals based on health status-related factors in any way.

At the other end of the spectrum are programs that are easily classified as standard-based under the 2006 Rule: "Status-dependent" programs that provide rewards only to individuals who fall within particular health-related parameters clearly would be subject to the five requirements. Similarly, "results-dependent" programs that provide rewards to individuals who achieve a particular outcome as the result of an interventional program (e.g., by actually quitting smoking or achieving a pre-defined weight loss or fitness goal) would also be treated as standard-based. ${ }^{138}$ These programs condition a reward on a standard related to health factors, whether by singling out particular individuals directly based on health status (e.g., RAND Employer D's \$754 premium differential tied to biometric data and clinical test results) or by doing so at the conclusion of an interventional program (e.g., the small percentage of employers who report offering financial incentives for diet or exercise programs tied to the achievement of particular weight loss goals).

138 The examples provided in the 2006 Rule to illustrate standardsbased programs that do and do not comply with the five requirements all describe programs that provide rewards based solely on whether an employee falls within defined health-factor parameters. See 29 C.F.R. $\S$ 2590.702(f)(3)(Example 2) (2007) (superseded) ("A group health plan offers an annual premium discount of 20 percent of employee-only coverage to participants who adhere to a wellness program. The wellness program consists solely of giving an annual cholesterol test to participants. Those participants who achieve a count under 200 receive the premium discount for the year."); 29 C.F.R. § 2590.702(f)(3) (Example 4) (2007) (superseded) ("A group health plan will waive the $\$ 250$ deductible ... for the following year for participants who have a body mass index between 19 and $\left.26^{\prime \prime}\right) ; 29$ C.F.R. § 2590.702(f)(3) (Example 5) (2007) (superseded) ('In conjunction with an annual open enrollment period, a group health plan provides a form for participants to certify that they have not used tobacco products in the preceding twelve months. Participants who do not provide the certification are assessed a surcharge that is 20 percent of the cost of employee-only coverage."). 
While some programs are easily classified as standardbased or not, the status of other programs described in the RAND study was somewhat ambiguous under the 2006 Rule - particularly those that I have described above as "targeted" and "two-tier" (see Table 3). The status of targeted and two-tier programs matters quite a lot given the RAND study's indication that results-based rewards are relatively rare, while targeted and two-tier programs appear to be more common. ${ }^{139}$ Targeted participation-only incentive programs (which identify particular individuals as eligible for interventional programs based on screening results, then offer rewards to eligible individuals for participation without regard to the results) could arguably have been classified either way under the 2006 Rule. Similarly, "two-tier" programs that require participation in an interventional program as an alternative pathway for individuals who fail to satisfy an initial biometric or risk factor standard straddle the line between the two types of programs described in the 2006 Rule. None of the examples provided in the 2006 Rule clearly describes either a targeted or two-tier program.

Table 3: Classifying Wellness Programs under the 2006 Rule

\begin{tabular}{|l|l|l|}
\hline $\begin{array}{c}\text { Clearly Non- } \\
\text { standard-based }\end{array}$ & \multicolumn{1}{|c|}{ Ambiguous } & $\begin{array}{c}\text { Clearly Standard- } \\
\text { based }\end{array}$ \\
\hline $\begin{array}{l}\text { Employer } \\
\text { Responsibility }\end{array}$ & $\begin{array}{l}\text { Targeted } \\
\text { Participation-only }\end{array}$ & $\begin{array}{l}\text { Status-dependent } \\
\text { Incentive Programs }\end{array}$ \\
\hline
\end{tabular}

139 See RAND Report, supra note 38, at 83 (indicating that although $69 \%$ of employers offer financial incentives for participation, only between 3 and $12 \%$ of those employers offer what the RAND report refers to as "results-based" incentives, depending on the type of program). As noted above, the RAND study did not explicitly distinguish between targeted and non-targeted participatory programs, but survey results identifying the percentage of "eligible" employees who participated in interventional programs suggest that many, if not most interventional programs target particular employees by basing eligibility on health status-related factors like smoking status or body mass index. 


\begin{tabular}{|c|c|c|}
\hline $\begin{array}{l}\text { Programs } \\
\text { (e.g., } \\
\text { employer offers a } \\
\text { healthy, low-cost } \\
\text { lunch special in } \\
\text { the cafeteria) } \\
\text { Non-targeted } \\
\text { Participation- } \\
\text { only Incentive } \\
\text { Programs } \\
\text { (e.g., any } \\
\text { individual is } \\
\text { eligible to receive } \\
\text { a premium } \\
\text { discount for } \\
\text { participation in } \\
\text { an onsite health } \\
\text { screening or } \\
\text { physical fitness } \\
\text { program, without } \\
\text { regard to results) }\end{array}$ & $\begin{array}{l}\text { Incentive } \\
\text { Programs } \\
\quad \text { (e.g., } \\
\text { individuals are } \\
\text { deemed eligible for } \\
\text { participation in an } \\
\text { on-site weight } \\
\text { management } \\
\text { program if their } \\
\text { body mass index is } \\
26 \text { or higher; } \\
\text { eligible } \\
\text { individuals receive } \\
\text { a premium } \\
\text { discount for } \\
\text { attending the } \\
\text { program, } \\
\text { regardless of } \\
\text { results) } \\
\text { Two-tier } \\
\text { Programs } \\
\text { (e.g., } \\
\text { individuals with } \\
\text { body mass index } \\
\text { under } 26 \text { receive a } \\
\text { premium discount; } \\
\text { individuals with } \\
\text { body mass index of } \\
26 \text { or above are } \\
\text { eligible to receive } \\
\text { the same discount } \\
\text { only if they attend } \\
\text { a weekly onsite } \\
\text { weight-loss } \\
\text { program }\end{array}$ & $\begin{array}{l}\text { (e.g., a premium } \\
\text { surcharge is } \\
\text { imposed on all } \\
\text { individuals with a } \\
\text { body mass index } \\
\text { above 26) } \\
\text { Results-dependent } \\
\text { Incentive Programs } \\
\text { (e.g., individuals } \\
\text { who lose } 5 \% \text { of their } \\
\text { body weight over a } \\
\text { defined period of } \\
\text { time earn a } \\
\text { premium discount) }\end{array}$ \\
\hline
\end{tabular}

The 2006 Rule states that "if any of the conditions for obtaining a reward under a wellness program is based on an 
individual satisfying a standard that is related to a health factor," then it must satisfy the five requirements to comply with HIPAA's prohibition on health-status discrimination. ${ }^{140} \quad$ Ultimately, targeted and two-tier programs allow individuals to earn rewards merely for participating in an interventional program and therefore do not truly require individuals to satisfy a standard related to a health factor to obtain a reward. An interpretation that equates being "based on" satisfaction of a health-related standard with "requiring" satisfaction of a health-related standard as the only means to earn a reward would be reasonable and would exempt targeted and two-tier programs from the five requirements. Indeed, the information reported about the two RAND employers that have health status and risk factor reward adopted two-tier programs does not appear to indicate that the employers have treated those programs as being subject to the five requirements that the 2006 Rule set forth for standardbased programs. ${ }^{141}$

On the other hand, it would also be reasonable to interpret "based on" satisfaction of a health related standard more broadly to encompass programs that single out particular individuals for differential treatment based on whether they satisfy an initial health-related standard. Under this interpretation, targeted and two-tier programs would be subject to the five requirements.

Two-tier programs designate particular individuals for differential treatment by requiring them to participate in an intervention program to earn the same reward that other individuals earn simply by being themselves. Under RAND Employer A's two-tier program, for example, non-smokers added).

140 See 29 C.F.R. $§ 2590.702(\mathrm{f})(2)$ (2007) (superseded) (emphasis

141 The report specifically notes that Employer D's statusdependent incentive program complies with the 2006 Rule by offering an alternative standard to employees for whom it would be impossible due to a medical condition to achieve or medically inadvisable to attempt satisfaction of the primary standard. See RAND Report, supra note 38 , at 86 . Similar information is notably absent with regard to the two-tier programs offered by Employers A and C. 
automatically avoid the $\$ 50$ annual insurance premium surcharge, while smokers must participate in an interventional program to avoid the penalty. Two-tier programs might be characterized as status-dependent incentive programs that include a second tier to meet the "reasonable alternative standard" requirement. If that is the case, however, then the adoption of a second tier to satisfy (and only partially) one of the five requirements of the 2006 Rule should not automatically exempt the program from the remaining requirements set forth for standardbased programs by reclassifying it as non-standard-based. For example, simply because RAND Employer A offers a participation-only pathway to receive the same reward offered to non-smokers based on their status alone, should not mean that the employer is exempt from offering an alternative to participating in the cessation program (which may include the use of cessation aids like nicotine patches or gum) for individuals for whom it would be medically inadvisable.

Targeted programs designate particular individuals for differential treatment by deeming them eligible for participation-dependent rewards while other individuals are not. Although targeted programs might be understood as giving preferential treatment to "unhealthy" individuals while deeming "healthier" individuals ineligible for incentives, the singling out of particular individuals as "unhealthy" and in need of education, instruction, counseling, or physical activity could create a hostile work environment. This concern is particularly salient for employees targeted on the basis of their weight, given that weight-based employment discrimination and harassment is widespread and has significant negative impacts on both physical and psycho-social health. ${ }^{142}$

To the extent that the 2006 Rule's definition of standardbased wellness programs could be construed narrowly to subject only status- and results-dependent programs to

142 See Wiley, Shame, supra note 18, at 174 (describing the ways in which workplace wellness programs might contribute to stigma and discrimination based on weight). 
significant regulation, the wellness program exception to HIPAA's general prohibition on health-factor discrimination was quite broad. The status of targeted and two-tier programs is important. As noted above, the RAND study indicates that these types of programs are considerably more common than status and results-dependent programs. While they do not raise the specter of "backdoor" health-status underwriting to quite the same extent that status-dependent programs do, they could drive away "unhealthy" employees by creating an environment that is hostile to those who smoke, are overweight, or have other biometric risk factors. In this sense, targeted and two-tier programs (just like status-dependent programs) might cut an employer's health care costs not by prompting employees to become healthier, but rather by shifting costs onto unhealthy employees. Status-dependent programs shift costs to unhealthy employees directly by charging them higher deductibles, copays or coinsurance. Targeted, twotier, and results-dependent programs have the potential to shift costs away from an employer by driving unhealthy employees out of that particular employer's workforce.

\section{The Wellness Program Exception in the $A C A$}

Inspired by media reports of successful employer wellness programs, ${ }^{143}$ Congress adopted and expanded the wellness program exception in 2010 as part of the ACA. As noted above, the ACA incorporated language from HIPPA's statutory text. ${ }^{144}$ It also incorporated significant language

143 See Steven A. Burd, How Safeway Is Cutting Health-Care Costs, WALL ST. J. (June 12, 2009, 12:01 AM), http://online.wsj.com/article/ SB124476804026308603.html (an op-ed piece by the CEO of Safeway, Inc., arguing that Congress should "raise the federal legal limits" on workplace wellness incentives), archived at http://perma.cc/9FTXLUWN; Hilzenrath, supra note 74 (describing how reports regarding the Safeway wellness program influenced the workplace wellness amendment and questioning previous reports of the Safeway program's success).

144 See supra note 123. 
from the 2006 Rule. ${ }^{145}$ Particularly interesting, however, are the subtle changes that Congress made to the exception. On the one hand, Congress seemingly "doubled down" on wellness programs by raising the cap on the overall value wellness program incentives from $20 \%$ to $30 \%$ across the board with flexibility for implementing agencies to raise it as high as $50 \% .{ }^{146}$ On the other hand, the text of the ACA includes a few other seemingly minor alterations to the language of the 2006 Rule. In particular, the ACA added a key phrase to its description of the uniform availability requirement ${ }^{147}$ confirming that DHHS has flexibility to

145 See supra note 124.

146 Under the 2006 Rule, the combined reward for achieving all available wellness program standards could not exceed $20 \%$ of the employee's cost of coverage under the plan. See 29 C.F.R. § $2990.702(f)(2)(i)$ (2007) (superseded). The ACA raises this cap to $30 \%$ and gives the Secretaries of Labor, Treasury, and Health and Human Services additional authority to extend it to $50 \%$. See 42 U.S.C. $\S$ $300 \mathrm{gg}-4(\mathrm{j})(3)(\mathrm{A})$.

147 Compare 29 C.F.R. $§ 2590.702$ (2)(iv) (2007) (superseded) ("The reward under the program must be available to all similarly situated individuals. (A) A reward is not available to all similarly situated individuals for a period unless [the program makes a reasonable alternative standard or waiver available to particular employees for whom it would be unreasonably difficult due to a medical condition to achieve or medically inadvisable to attempt to satisfy the otherwise applicable standard].") with 42 U.S.C. $\$ 300 \mathrm{gg} \cdot 4(\mathrm{j})(3)(\mathrm{D})$ (2014) ("The full reward under the wellness program shall be made available to all similarly situated individuals. For such purposes, among other things: (i) The reward is not available to all similarly situated individuals for a period unless [the program makes a reasonable alternative standard or waiver available to particular employees for whom it would be unreasonably difficult due to a medical condition to achieve or medically inadvisable to attempt to satisfy the otherwise applicable standard].") (emphasis added). The addition of the phrase "among other things" in the text of the ACA provides additional support for the argument that Congress intended to grant the implementing agencies discretion to impose additional requirements as the agency deemed necessary. Thus, although commentators do not appear to have anticipated that the 2013 Rule would be considerably more protective of employees than the 2006 Rule, the greater protection provided by the agencies in the 2013 Rule appears to be consistent with the language of the statute and with congressional intent to prohibit the use of wellness programs as a subterfuge for health-status discrimination. Other subtle changes also 
impose additional regulatory requirements on the most concerning types of programs to ensure that incentives are available to all employees and not used as a subterfuge for discrimination, as Congress intended. These subtle, but important changes paved the way for DHHS to narrow the wellness program exception in the 2013 Rule, as described below.

\section{The 2013 Wellness Program Rule}

The Final Rule on Incentives for Nondiscriminatory Wellness Programs in Group Health Plans issued by DHHS and the Departments of Labor and Treasury in 2013 fleshed out the wellness program exception in considerably greater detail than the 2006 Rule. Ultimately, the 2013 Rule significantly narrowed the wellness program exception to HIPAA and ACA non-discrimination provisions by subjecting broader categories of programs to more stringent requirements and thus affording greater protection to employees from health-related discrimination.

The 2013 Rule labels and defines three categories of wellness programs: (1) "participatory wellness programs," (2) "activity-only health-contingent wellness programs," and (3) "outcome-based health-contingent wellness programs" and subjects each to distinct regulatory requirements. First, the 2013 Rule re-styles the non-standard-based category from the 2006 Rule as "participatory" and the

indicate congressional intent to give the agency discretion to tighten the regulations applicable to wellness programs. For example, a partial grandfathering clause notes that wellness programs established prior to the enactment of the ACA that complied with all applicable regulations (presumably referencing the 2006 Rule) may continue to be carried out for as long as those regulations remain in effect. The most reasonable interpretation of this provision is that Congress intended for wellness programs that pre-date the ACA (and were compliant with the 2006 Rule) to be required to comply with any more stringent regulations that the agencies might ultimately promulgate superseding the 2006 Rule. See 42 U.S.C. § $300 \mathrm{gg}-4(\mathrm{k})(2)(2014)$. 
standard-based category as "health-contingent."148 It then defines "health-contingent" more clearly than the 2006 Rule defined "standards-based." Under the 2013 Rule, the implementing agencies classify a program as healthcontingent (and thus subject to the five requirements) if it "requires an individual to satisfy a standard related to a health factor to obtain a reward" or "requires an individual to undertake more than a similarly situated individual based on a health factor in order to obtain the same reward." 149 In doing so, the agencies effectively adopt the broader reading of the phrase "based on an individual satisfying a standard that is related to a health status factor" (which was imported from the 2006 Rule into the text of the ACA), discussed above. Whereas the status of targeted and two-tier programs under the 2006 Rule was ambiguous and there was some evidence in the RAND report that employers did not treat them as subject to the five requirements, under the 2013 Rule, targeted and twotier programs are clearly treated as health-contingent and subjected to greater regulation.

The 2013 Rule goes on to subdivide health-contingent programs into "activity-only" and "outcome-based." "An activity-only wellness program is a type of healthcontingent wellness program that requires an individual to perform or complete an activity related to a health factor in order to obtain a reward but does not require the individual to attain or maintain a specific health outcome."150 This definition encompasses targeted participation-only incentive programs, which single individuals for participation based on health factors and further "relate to" those health factors by aiming to alter them. ${ }^{151}$

Arguably, activity-only health-contingent programs

148 See 29 C.F.R. $\S 2590.702(f)(1)(i i)$ (2014) (defining participatory wellness programs); id. at $\S 2590.702\left(f^{\prime}\right)(1)(i i i)$ (defining healthcontingent wellness programs).

149 Id.

$150 \mathrm{Id}$

151 The examples provided in the Rule describe a participation-only walking program that targets individuals based on body mass index as an activity only program. See id. $§ 2590.702(f)(4)(v i)($ Example 4)(ii). 
would also encompass all participation-only incentive programs, but there must be a sensible line between participatory programs and activity-only health-contingent programs, given that the 2013 Rule recognizes a "participatory wellness program" category and subjects it to minimal regulation in the way that the 2006 Rule treated "non-standard-based" programs. The examples of participatory programs provided in the 2013 Rule all describe either employer responsibility programs ${ }^{152}$ or nontargeted participation-only incentive programs that do not require physical activity. ${ }^{153}$ The examples of activity-only health-contingent programs provided in the 2013 Rule include what appears to be a non-targeted participationonly incentive program that does require physical activity. ${ }^{154}$ A sensible conclusion then is that although most non-targeted participation-only incentive programs are

152 See id. $§ 2590.702(\mathrm{f})(1)(\mathrm{ii})(\mathrm{A})$ ("A program that reimburses employees for all or part of the cost for membership in a fitness center."); id § 2590.702(f)(1)(ii)(C) ("A program that encourages preventive care through the waiver of the copayment or deductible requirement under a group health plan for the costs of, for example, prenatal care or well-baby visits.").

${ }_{153}$ See id. $§ 2590.702(\mathrm{f})(1)(\mathrm{ii})(\mathrm{B})$ ("A diagnostic testing program that provides a reward for participation in that program and does not base any part of the reward on outcomes."); id $\S 2590.702(\mathrm{f})$ (1)(ii)(D) ("A program that reimburses employees for the costs of participating or that otherwise provides a reward for participating, in a smoking cessation program without regard to whether the employee quits smoking."); id $\S$ $2590.702(\mathrm{f})(1)(\mathrm{ii})(\mathrm{E})$ ("A program that provides a reward to employees for attending a monthly, no-cost health education seminar."); id $\S$ 2590.702(f)(1)(ii)(F) ("A program that provides a reward to employees who complete a health risk assessment regarding current health status, without any further action (educational or otherwise) required by the employee with regard to the health issues identified as part of the assessment.").

154 See id. $\$ 2590.702(\mathrm{f})(3)(\mathrm{iv})$ ("A group health plan provides a reward to individuals who participate in a reasonable specified walking program. If it is unreasonably difficult due to a medical condition for an individual to participate (or if it is medically inadvisable for an individual to attempt to participate), the plan will waive the program requirement and provide the reward. All materials describing the terms of the walking program disclose the availability of the waiver. . . The program satisfies [the five requirements]."). 
treated as "participatory" under the 2013 Rule, targeted participation-only incentive programs that require physical activities that may be inaccessible to some employees based on their health factors are regulated as activity-only healthcontingent programs. ${ }^{155}$ Notably, these programs might readily have been understood to be non-standards-based programs that were subject to the most minimal regulation under the 2006 rule, while the 2013 Rule subjects them to the five requirements.

Finally, outcome-based health-contingent wellness programs are defined to encompass any program "that requires an individual to attain or maintain a specific health outcome (such as not smoking or attaining certain results on biometric screenings) in order to obtain a reward." 156 This definition clearly encompasses the statusand results-dependent incentive programs that were already subject to the five requirements under the 2006 Rule. But the 2013 Rule goes on to clarify that the fact that an outcome-based wellness program offers an alternative pathway to obtain the same reward (via participation in an intervention program) to all individuals who fail to meet the initial standard (as required by the heightened "reasonable

155 Some confusion remains, however, about the status of targeted participation-dependent incentive programs for smoking cessation under the 2013 Rule. A workplace wellness program that directs identified smokers to a smoking cessation program and provides them with a reward for participation regardless of whether they actually quit smoking would seem to fit the regulatory definition of an activity-only health-contingent program, subject to the weaker form of the five requirements. A two-tiered program that identifies non-smokers and rewards them and then offers the same reward to smokers only if they participate in a smoking cessation program would be bumped up to an outcome-based health-contingent program subject to the stronger form of the five requirements. On the other hand, the 2013 Rule describes an incentive for participating in a smoking cessation program as an example of a participatory program not subject to the five requirements at all. Notably, smoking status is also singled out for less protection by the higher cap on rewards for smoking cessation programs. As noted above, the differential treatment of smoking may be explained by the fact that an independent ACA provision permits insurers to charge higher premiums to tobacco users (at a ratio of 1 to 1.5).

156 Id. $\S 2590.702(\mathrm{f})(1)(\mathrm{v})$. 
design" requirement described below) does not render the program "participatory" or even "activity-based."157 "[I]f a measurement, test, or screening program is used as part of an initial standard and individuals who meet the standard are granted the reward, the program is considered an outcome-based wellness program." The regulations also provide an example for further clarification:

[I]f a wellness program tests individuals for specified medical conditions or risk factors (including biometric screening such as testing for high cholesterol, high blood pressure, abnormal body mass index, or high glucose level) and provides a reward to individuals identified as within a normal or healthy range for these medical conditions or risk factors, while requiring individuals who are identified as outside the normal or healthy range (or at risk) to take additional steps (such as meeting with a health coach, taking a health or fitness course, adhering to a health improvement action plan, complying with a walking or exercise program, or complying with a health care provider's plan of care) to obtain the same reward, the program is an outcome-based wellness program. ${ }^{158}$

Thus, two-tier programs (which were arguably nonstandard-based programs under the 2006 Rule) are clearly subject to the most stringent regulation under the 2013 Rule. Table 4 summarizes the classification of various types of wellness programs under the 2013 Rule. 
Table 4: Classifying Wellness Programs under the 2013 Rule

\begin{tabular}{|c|c|c|}
\hline Participatory & $\begin{array}{c}\text { Activity-based } \\
\text { Health Contingent }\end{array}$ & $\begin{array}{l}\text { Outcome- } \\
\text { based Health } \\
\text { Contingent }\end{array}$ \\
\hline $\begin{array}{l}\text { Employer } \\
\text { Responsibility } \\
\text { Programs } \\
\text { (e.g., employer } \\
\text { offers a healthy, } \\
\text { low-cost lunch } \\
\text { special in the } \\
\text { cafeteria) } \\
\text { Non-targeted } \\
\text { Participation-only } \\
\text { Incentive Programs } \\
\text { that do not involve } \\
\text { physical activity } \\
\text { (e.g., any } \\
\text { individual is } \\
\text { eligible to receive a } \\
\text { premium discount } \\
\text { for participation in } \\
\text { an onsite health } \\
\text { screening or health } \\
\text { education seminar, } \\
\text { without regard to } \\
\text { results) }\end{array}$ & $\begin{array}{l}\text { Non-targeted } \\
\text { Participation-only } \\
\text { Incentive Programs } \\
\text { that involve } \\
\text { physical activity } \\
\quad \text { (e.g., any } \\
\text { individual is } \\
\text { eligible to receive a } \\
\text { reduction in their } \\
\text { co-pay for } \\
\text { participating in a } \\
\text { walking program, } \\
\text { without regard to } \\
\text { results) } \\
\text { Targeted } \\
\text { Participation-only } \\
\text { Incentive Programs } \\
\quad \text { (e.g., individuals } \\
\text { are deemed eligible } \\
\text { for participation in } \\
\text { an on-site weight } \\
\text { management } \\
\text { program if their } \\
\text { body mass index is } \\
26 \text { or higher; } \\
\text { eligible individuals } \\
\text { receive a premium } \\
\text { discount for } \\
\text { attending the } \\
\text { program, } \\
\text { regardless of }\end{array}$ & $\begin{array}{l}\text { Status-dependent } \\
\text { Incentive } \\
\text { Programs } \\
\quad \text { (e.g., a } \\
\text { premium } \\
\text { surcharge is } \\
\text { imposed on all } \\
\text { individuals with a } \\
\text { body mass index } \\
\text { above 26) } \\
\\
\text { Results- } \\
\text { dependent } \\
\text { Incentive } \\
\text { Programs } \\
\quad \text { (e.g., } \\
\text { individuals who } \\
\text { lose } 5 \% \text { of their } \\
\text { body weight over } \\
\text { a defined period of } \\
\text { time earn a } \\
\text { premium } \\
\text { discount) } \\
\text { Two-tier } \\
\text { Programs } \\
\text { (e.g., } \\
\text { individuals with } \\
\text { body mass index } \\
\text { under } 26 \text { receive a } \\
\text { premium } \\
\text { discount; }\end{array}$ \\
\hline
\end{tabular}




\begin{tabular}{|l|l|l|}
\hline results) & $\begin{array}{l}\text { individuals with } \\
\text { body mass index } \\
\text { of } 26 \text { or above are } \\
\text { eligible to receive } \\
\text { the same discount } \\
\text { only if they attend } \\
\text { a weekly onsite } \\
\text { weight-loss } \\
\text { program }\end{array}$ \\
\hline
\end{tabular}

In addition to resolving ambiguity over which categories of plans are subject to the five requirements, the 2013 Rule also elaborates upon those requirements in a way that ensures their stringency as a barrier to "back-door" healthbased underwriting. The 2013 Rule creates two distinct versions of the five requirements imported from the 2006 Rule into the ACA-one for activity-based programs and another for outcome-based programs-and elaborates additional factors and requirements applicable to each. Table 5 summarizes these regulatory requirements. 
Table 5: Regulation of Wellness Programs under the 2013 Rule

\begin{tabular}{|c|c|c|}
\hline Participatory & $\begin{array}{l}\text { Activity- } \\
\text { based Health- } \\
\text { contingent }\end{array}$ & $\begin{array}{r}\text { Outcome-based } \\
\text { Health-contingent }\end{array}$ \\
\hline $\begin{array}{l}\text { Participation in } \\
\text { the program } \\
\text { must be made } \\
\text { available to all } \\
\text { similarly } \\
\text { situated } \\
\text { individuals. }\end{array}$ & $\begin{array}{l}\text { Same as the five } \\
\text { requirements } \\
\text { under the } 2006 \\
\text { Rule, except: } \\
\text { 1) Cap on } \\
\text { reward value is } \\
\text { raised to } 30 \% \\
\text { (50\% for } \\
\text { smoking). } \\
\text { 2) If the } \\
\text { reasonable } \\
\text { alternative } \\
\text { standard is an } \\
\text { educational } \\
\text { program, the } \\
\text { plan must make } \\
\text { it available or } \\
\text { assist the } \\
\text { employee in } \\
\text { finding a } \\
\text { program, the } \\
\text { time } \\
\text { commitment } \\
\text { must be } \\
\text { reasonable, and } \\
\text { if the } \\
\text { alternative is a } \\
\text { diet program, } \\
\text { the plan must } \\
\text { pay the }\end{array}$ & $\begin{array}{l}\text { Same as for activity- } \\
\text { based programs, } \\
\text { except: } \\
\text { 1) The program must } \\
\text { provide an alternative } \\
\text { standard to any } \\
\text { individual who does } \\
\text { not meet the initial } \\
\text { standard; the plan } \\
\text { may not seek } \\
\text { verification from an } \\
\text { individual's personal } \\
\text { physician that a } \\
\text { health factor makes it } \\
\text { unreasonably difficult } \\
\text { for the individual to } \\
\text { satisfy, or medically } \\
\text { inadvisable to attempt } \\
\text { to satisfy the } \\
\text { otherwise applicable } \\
\text { standard. } \\
\text { 2) If the alternative } \\
\text { standard is itself an } \\
\text { outcome-based } \\
\text { program, it too must } \\
\text { comply with the five } \\
\text { requirements. } \\
\text { 3) The alternative } \\
\text { standard cannot be a } \\
\text { requirement to meet a }\end{array}$ \\
\hline
\end{tabular}




\begin{tabular}{|c|c|c|}
\hline & \begin{tabular}{|l|} 
membership or \\
participation \\
fee. \\
3) The \\
alternative \\
standard must \\
accommodate \\
any \\
recommendation \\
s of the \\
individual's \\
personal \\
physician \\
regarding \\
medical \\
appropriateness \\
4) If the \\
alternative \\
standard is \\
itself an \\
activity-only \\
program, it too \\
must comply \\
with the five \\
requirements
\end{tabular} & $\begin{array}{l}\text { different level of the } \\
\text { same standard } \\
\text { without additional } \\
\text { time. } \\
\text { 4) An individual must } \\
\text { be given the } \\
\text { opportunity to comply } \\
\text { with the } \\
\text { recommendations of } \\
\text { her personal physician } \\
\text { as an alternative to } \\
\text { meeting the } \\
\text { alternative standard } \\
\text { defined by the plan. }\end{array}$ \\
\hline
\end{tabular}

The most notable enhancement to the requirements for activity-only programs relate to the uniform availability and reasonable alternative standard requirements. To be considered uniformly available, an outcome-based program must allow a reasonable alternative standard for obtaining the same reward (or a waiver of the standard altogether) for any individual for whom it is unreasonably difficult due to a medical condition to satisfy or medically inadvisable to attempt to satisfy the otherwise applicable standard. ${ }^{159}$ The

159 Id. $§ 2590.702(f)(3)(\mathrm{iv})(\mathrm{A})(1)-(2)$. The Rule clarifies that a plan or issuer may seek verification, including a statement from an 
Rule also specifies several factors that will be among those taken into account in determining whether the program satisfies the uniform availability requirement: "If the reasonable alternative standard is completion of an educational program, the plan or issuer must make the educational program available or assist the individual in finding such a program (instead of requiring an individual to find such a program unassisted), and may not require an individual to pay for the cost of the program." 160 Additionally, "[i]f the reasonable alternative standard is a diet program, the plan or issuer is not required to pay for the cost of food but must pay any membership or participation fee."161 The time commitment required must also be reasonable. 162

With regard to outcome-based programs, the reasonable design requirement is significantly expanded as compared to the 2006 Rule. "To ensure that an outcome-based wellness program is reasonably designed to improve health and does not act as a subterfuge for underwriting or reducing benefits based on a health factor, a reasonable alternative standard to qualify for the reward must be provided to any individual who does not meet the initial standard based on the measurement, test, or screening that is related to a health factor."163 This is an important new requirement that will go a long way toward ensuring that wellness programs are not simply used to shift costs onto less healthy individuals. Previously, the only individuals for whom a reasonable alternative standard must be offered were those whose personal physicians could verify, upon request, that they met the "unreasonably difficult/medically inadvisable" standard. The 2013 requirement, in contrast, requires an alternative pathway for all individuals who do

individual's personal physician that an employee falls into this category. See id. § $2590.702(\mathrm{f})(3)(\mathrm{iv})(\mathrm{E})$.

$160 \quad I d . \$ 2590.702 \quad(\mathrm{f})(3)(\mathrm{iv})(\mathrm{C})(1) . \quad$ Presumably the same requirement would apply to the initial standard and not only the reasonable alternative standard.

161 Id. $\$ 2590.702$ (f)(3)(iv)(C)(3).

162 Id. $\S 2590.702(\mathrm{f})(3)(\mathrm{iv})(\mathrm{C})(2)$.

163 Id. $\S 2590.702(\mathrm{f})(4)$ (iii) (emphasis added). 
not meet the initial outcome-based standard. This requirement effectively renders status ${ }^{-}$and resultdependent programs (which surveys indicate are extremely popular among large employers) considerably less attractive by imposing considerable burdens on employers or health plans to pay for individuals to participate in alternative programs and by allowing many employees to obtain the same reward without satisfying outcome-based standards (by requiring programs to offer compliance with the recommendations of the individual's personal physician as an alternative, regardless of whether the individual has a medical excuse for not satisfying or attempting to satisfy the initial standard. It requires that these programs follow the two-tier model, and it seems likely that in many cases, that second (or third, or fourth) alternative tier will ultimately have to be a non-outcome-based alternative.

\section{Support for Small Business Workplace Wellness Programs}

In addition to the wellness-programs exception for group health plans, the ACA authorized the appropriation of $\$ 200$ million for grants to businesses with fewer than 100 employees to establish "comprehensive" workplace wellness programs. ${ }^{164}$ The statute defined "comprehensive' programs as those that include (1) "[h] ealth awareness initiatives (including health education, preventive screenings, and health risk assessments)"; (2) "[e]fforts to maximize employee engagement (including mechanisms to encourage employee participation)"; (3) "[i]nitiatives to change unhealthy behaviors and lifestyle choices (including counseling, seminars, online programs, and self-help materials)"; and (4) "[s]upportive environment efforts (including workplace policies to encourage healthy lifestyles, healthy eating, increased physical activity, and improved mental health)."165

164 See Patient Protection and Affordable Care Act, Pub. L. No. 111148, 124 Stat. $119,978, \S 10408(e)$ (2010).

165 Id. 
Congress has failed to appropriate funds for the statutory grant program. Nonetheless, in 2011, DHHS announced that it was making $\$ 10$ million from the ACA's Prevention and Public Health Fund available to support workplace wellness programs for employers with fewer than 100 employees that did not previously have a program in place. ${ }^{166}$ This program appears to be responsive to some aspects of the statutory small business grants while also fulfilling another ACA provision's mandate that the U.S. Centers for Disease Control and Prevention provide technical support for workplace wellness provisions. ${ }^{167}$ The agency ultimately awarded grants to establish and evaluate a new national network to provide technical support to between 70 and 100 large and small employers developing new wellness programs. ${ }^{168}$

While the statutory criteria for the small business grant program primarily emphasize personal responsibility programs and incentives for participation in them, the program that DHHS ultimately created has a much stronger emphasis on employer responsibility. The concrete examples described in the award announcement could all be described as employer responsibility programs with a particular emphasis on changes to the worksite environment: "Tobacco-free campus policy, subsidized quitsmoking counseling (quitlines, health plans, others) [; w]orksite farmer's market, nutrition counseling/education, menu labeling on healthy foods, healthy foods in cafeterias and vending, weight management counseling[; and s]tairwell enhancement, physical fitness/lifestyle

166 Press Release, Dep't Health and Human Servs., $\$ 10$ Million in Affordable Care Act Funds to Help Create Workplace Health Programs (June 23, 2011).

167 See 42 U.S.C. $\S 2801$ (2014); see also Healthier Worksite Initiative, CTRS. FOR DISEASE CONTROL AND PREVENTION, http://www.cdc.gov/nccdphp/dnpao/hwi/ (last updated Feb. 9, 2010) (The CDC provides this support directly, in addition to funding support and evaluation by private organizations.).

168 Workplace Health Promotion, CTRS. FOR DiSEASE CONTROL AND PREVENTION, http://www.cdc.gov/workplacehealthpromotion/nhwp/ (last updated Oct. 23, 2013), archived at http://perma.cc/8UDD-AZ76. 
counseling, walking trails/clubs, flextime policy."169 The announcement also notes that successful programs will "create a health-promoting environment that establishes a culture of health within the worksite."170

\section{The Individual Insurance Wellness Program Demonstration Project}

Although the ACA extended anti-discrimination protections to the individual market, the wellness program exception discussed above remains restricted to the group market. Rather than allowing individual-market insurers to adopt wellness programs right away, the statute mandated that DHHS establish a ten-state demonstration project whereby states will be allowed to apply the wellness program provisions to the individual market. ${ }^{171}$ By statute, the initial demonstration project must be established no later than July 2014, with authorization to extend the program to additional states in 2017.

The statute sketches out several requirements for approval of a state's participation in the demonstration project, designed to ensure that the program does not run counter to the ACA's broader goals. States may permit premium discounts or rebates or alter otherwise applicable copays or deductibles as a reward for "adherence to, or participation in, a reasonably designed program of health promotion and disease prevention."172 However, the Secretaries must design the project so as to avoid any decrease in coverage or increase in cost to the federal government in terms of premium assistance and costsharing reduction subsidies offered via the Exchanges. ${ }^{173}$ Participating states must also ensure that various consumer protection requirements imposed on individualmarket plans are satisfied by demonstration project plans

$\begin{array}{ll}169 & I d . \\ 170 & I d . \\ 171 & \text { See } 42 \text { U.S.C. } \S 300 \mathrm{~g}-4(\)(2014) . \\ 172 & \text { Id. } \\ 173 & \text { Id. } \S 300 \mathrm{~g}-4 \text { (3)(A)(i)-(ii). }\end{array}$


and must require verification from participating health insurance issuers that discounts "do not create undue burdens" for insureds, "do not lead to cost shifting," and "are not a subterfuge for discrimination." 174

While the mid-2014 deadline looms closer, as of this writing, DHHS has taken no apparent action to implement it. The agencies did not address the demonstration project in any way in the 2013 Rule, in spite of comments from the American Association of Health Plans urging them to do so. ${ }^{175}$

\section{E. The Medicaid Incentives for Prevention of Chronic Disease Program}

Just as many private health plans have adopted incentive-based personal responsibility for wellness programs, several states (who take on the role of third party payers with respect to the Medicaid program) have also sought to establish incentive-based personal responsibility for wellness programs for Medicaid recipients. Federal law restrains the ability of states to impose premium contributions and cost-sharing arrangements on Medicaid recipients, but those restraints were loosened considerably by the 2005 Deficit Reduction Act ("DRA"). Shortly thereafter, DHHS granted several section 1115 waivers that allowed states to adopt a wide range of experimentation in this area. As described below, DHHS implementation of this program reflects growing skepticism toward programs that tie the terms of coverage to risk factors and health

174 Id.

175 Letter from Daniel T. Durham, Executive Vice President, \& Thomas J. Wilder, Senior Counsel, America's Health Insurance Plans, to U.S. Department of Labor 9 (Jan. 25, 2013) ("It will take time for states to apply for the Demonstration Project and design wellness programs and for insurers to implement the programs. We believe it is critical for HHS to work with stakeholders and to release the program requirements as soon as possible in order to allow such wellness programs in the individual market starting in 2014."), available at http://op.bna.com/hl.nsf/id/shad94dsh2/\$File/Wellness\%20Incentives\%20Proposed\%20Rule\%20Comments\% 20(AHIP,\%2001.25.13).pdf, archived at http://perma.cc/53U-36A9. 
outcomes and greater emphasis on third-party-payer responsibility.

\section{Federal Restraints on the Implementation of Incentive-based Personal Responsibility for Wellness Medicaid Programs}

Medicaid was designed to meet the particular needs of very low-income families and disabled adults and thus has traditionally included many features that make it distinct from private health insurance. ${ }^{176}$ Prior to the DRA, states were prohibited from charging monthly premiums in any amount and nominal co-pays were permitted only for certain recipients. ${ }^{177}$ The DRA gives states considerably greater freedom to redesign their Medicaid programs in ways that bring them into line with typical private health plans. States are permitted to adopt these changes without the need for a section 1115 waiver, though they do require submission of a State Plan Amendment to DHHS.178 States are permitted to shift many recipients into privatized managed care plans. ${ }^{179}$ They may also charge monthly premiums to recipients living above $150 \%$ of the Federal Poverty Level ("FPL"). States may require greater cost sharing-up to the levels typically seen in many private health plans-for many Medicaid recipients ${ }^{180}$ (with the

176 The Medicaid Program at a Glance, THE HENRY J. KAISER FAMILY FOUND. (MAR. 4, 2013), http://kff.org/medicaid/fact-sheet/themedicaid-program-at-a-glance-update/, archived at http://perma.cc/ LJR9-KHPN.

177 See DeP'T OF Health \& Human Servs., The Deficit REDUCTION ACT: IMPORTANT FACTS FOR STATE GOVERNMENT OFFICIALS, available at http://www.cms.gov/Regulations-andGuidance/Legislation/DeficitReductionAct/downloads/Checklist1.pdf, archived at http://perma.cc/TU8C-MUVS.

178 DEP'T OF HEALTH AND HUMAN SERVICES, UNDERSTANDING MEDICAID HOME AND COMMUNITY SERVICES 163 (2000), available at http://aspe.hhs.gov/daltcp/reports/primer.pdf.

179 Deficit Reduction Act of 2005, Pub. L. 109-171, 120 Stat. 4, $\S$ 6044 (2006).

180 Recipients living above $100 \%$ FPL may be required to pay up to $10 \%$ of covered services; recipients above $150 \%$ FPL may be charged up 
exception of true emergency services, ${ }^{181}$ family-planning services, and preventive services for kids) are provided for recipients living above $100 \%$ FPL. ${ }^{182}$ States may also permit health care providers to require payment from recipients at the point of service before care is provided. The statute established a cap on aggregate premium and cost-sharing expenses, prohibiting them from exceeding 5\% of a family's monthly income, though enforcement of the cap may be beyond the administrative capacity of many state programs. Certain groups are protected from premiums and cost sharing, including children below independently specified levels of poverty, pregnant women, institutionalized adults, and those in hospice care. The door remained open for states to impose harsher premiums or cost sharing through section 1115 waivers.

\section{Medicaid Wellness Program Waivers Prior to the ACA}

In the years following passage of the DRA, DHHS granted section 1115 waivers quite liberally for stateinitiated demonstration projects that incorporated personal responsibility for wellness directly into the terms of coverage. Incentive-based programs in three statesFlorida, Idaho, and West Virginia-have garnered particular attention from researchers. Florida's program offered incentives for medical and lifestyle compliance. Idaho and West Virginia went considerably further, blurring the line between incentives and penalties by initially reducing the quality of coverage for all beneficiaries and then offering enhanced coverage as a reward for wellness program participation and results.

In 2005, Florida obtained a waiver ${ }^{183}$ that shifted many of the state's Medicaid recipients into private managed care

to $20 \%$. Id. $\S 6041$. Co-pays may also be charged for prescription drugs. Id. $\S 6042$.

181 A separate provision of the DRA specifically allows cost sharing for non-emergency use of emergency room services. Id. $\S 6043$.

182 Id. $\S \S 6041 \cdot 43$.

183 The initial waiver was granted for a five-year period. See CTRS. FOR MEDICARE \& MEDICAID SERVS., MEDICAID REFORM SECTION 1115 
plans and instituted the "Enhanced Benefit Reward\$ Program," which was designed to encourage individuals to improve their individual health behaviors. ${ }^{184}$ Recipients complying with any of nineteen identified health behaviors (ranging from getting a recommended pap smear or an annual flu shot to participating in smoking cessation, weight loss, or diabetes management programs), they became eligible for vouchers ranging in value $\$ 7.50$ to $\$ 25$, up to a total of $\$ 125$ per year. ${ }^{185}$ Vouchers were redeemable for medical goods not otherwise covered by Medicaid, like over-the-counter medicines and Band-Aids. ${ }^{186}$ The enhanced benefits can be placed into two categories: those that are services provided by a doctor and "community programs."187 Particularly for interventional lifestyle programs, which the Florida Plan defined as "community

DEMONSTRATION, available at http://www.fdhc.state.fl.us/Medicaid/ medicaid_reform/waiver/pdfs/cms_special_terms_and_conditions.pdf. It was then extended for three additional years. See Letter from Cindy Mann, Director, Ctrs. for Medicaid \& Medicare Servs., to Elizabeth Dudek, Secretary, Fla. Agency for Health Care Admin. (Dec. 15, 2011), available at http://www.fdhc.state.fl.us/Medicaid/medicaid_reform/pdf/ CMS_Approval_Letter_12-15-2011.pdf, archived at http://perma.cc/ PK4G-SE64.

184 Jessica Greene, CTr. for Health Care Strategies, InC., MEDICAID EFFORTS TO INCENTIVIZE HEALTHY BEHAVIORS 4 (2007), available at http://www.chcs.org/usr_doc/Medicaid_Efforts_to_ Incentivize_Healthy_Behaviors.pdf; PAT REDMOND ET AL., CENTER ON Budget AND POLICY PRIORITIES, CAN INCENTTVES FOR HEALTHY BeHAVIOR ImPRove Health AND Hold Down Medicaid Costs? 2

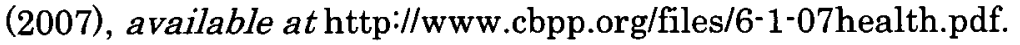

185 GreEne, supra note 184, at 1; FLA. AgENCY FOR HEALTH CARE Admin., ENHANCED BENEFITS REWARD\$ PROGRAM (2011), http://www.fdhc.state.fl.us/medicaid/medicaid_reform/enhab_ben/EBCod esAsOf_7_26_2011.pdf [hereinafter ENHANCED BENEFITS].

186 REDMOND ET AL., supra note 184, at 2; GREENE, supra note 184, at 7; ENHANCED BENEFITS, supra note 185.

187 C.f. ENHANCED BENEFITS, supra note 185 (listing all Enhanced Benefits as of July, 2011); Greene, supra note 184, at 4 (citing FLA. AGENCY FOR HEALTH CARE ADMIN., ENHANCED BENEFITS ACCOUNTS PROGRAM FREQUENTLY ASKED QUESTIONS [\#1] 4 (2006), available at http://www.fdhc.state.fl.us/Medicaid/medicaid_reform/enhab_ben/eb_acc ounts_program_faq1_091206.pdf [hereinafter ENHANCED BENEFITS FAQ]) (discussing community programs). 
programs" that have "defined goals and or milestones[,] provide information, guidance, and/or assistance for specific behaviors[,] and are accessible to the public"188-it was fairly onerous for recipients to obtain the vouchers. The recipient was required to submit an "Enhanced Benefit Universal Form" to the health plan. 189 The recipient was required to get a health care provider or the sponsor of the interventional program was required to specify the beginning and end dates of the healthy behavior, "and sign the form before forwarding it to the health plan." 190

An assessment of the Florida program published in 2013 found that virtually all of the rewards earned by participants in the program were for receiving recommended check-ups, with less than $1 \%$ of rewards received for participation in lifestyle programs, 191 representing two individuals (out of the more than 400,000 who were automatically enrolled in the program) who earned credits for participating in a smoking-cessation program (one of whom was not smoking six months after initiating the program) and two individuals who earned credits for participation in an exercise program. ${ }^{192}$ As of this writing, the Florida Enhanced Benefits program is being phased out ${ }^{193}$ while the state transitions to a new demonstration project, as described below.

In 2007, Idaho received a waiver to develop two incentive-based wellness programs, which the state referred

188 Greene, supra note 184, at 4 (citing ENHANCED BENEFITS FAQ, supra note 185 , at 4 ).

189 Lucinda Jesson, Weighing The Wellness Programs: The Legal Implications Of Imposing Personal Responsibility Obligations, 15 VA. J. SOC. POL'Y \& L. 217 (2008).

190 Id.

191 Blumenthal et al., supra note 14, at 499.

192 Id. at 498.

193 After July 1, 2014, recipients will no longer be able to earn vouchers, and after June 30,2015, recipients will not be able to redeem vouchers. See Letter from Melanie Brown-Woofter, Chief, Bureau of Health Sys. Dev., to Reform Health Plans (July 31, 2013), available at http://www.fdhc.state.fl.us/Medicaid/medicaid_reform/enhab_ben/DHP_RE_ Enhanced_Benefit_Program_Phase_Out_Notice_1_7-31-13.pdf, archived at http://perma.cc/WA6Q-P3CX. 
to as "Preventive Health Assistance" ("PHA") programs. ${ }^{194}$ The first, called the "Behavioral PHA" targeted individuals for weight management or smoking cessation. ${ }^{195}$ Participants were rewarded for meeting with a health-care provider to develop a weight-management or smokingcessation plan. Those who successfully quit smoking were entitled to a second reward. Although a results-dependent reward was initially planned for the weight-management program as well, it was ultimately determined that such a strategy put too much emphasis on losing weight, rather than on living healthfully. ${ }^{196}$ Similar to the Florida program, rewards under this program took the form of credits that could be used to pay for counseling, diet and exercise programs, and nicotine replacement products. ${ }^{197}$ An assessment published in 2013 found that fewer than 1500 (out of a pool of approximately 185,000 recipients) participated in the first two years of the program. ${ }^{198}$ The state did not assess the program's impact on actual cessation and weight control. ${ }^{199}$

Idaho's second program, called the "Wellness PHA," tied rewards directly to cost-sharing requirements by offering participants credits toward the payment of monthly premiums as a reward for reporting for recommended wellchild visits. ${ }^{200}$ An evaluation published in 2013 suggests that the program significantly increased the proportion of children who had received recommended well-child care.

194 GreEnE, supra note 165; Preventative Health Assistance, IDAHO DEP'T OF HEALTH AND WELFARE, http://healthandwelfare.idaho.gov/ Medical/Medicaid/PreventiveHealthAssistance/tabid/221/Default.aspx (last visited Dec. 5, 2013) [hereinafter Preventative Health Assistance], archived at http://perma.cc/K7NJ-F2JU.

195 REDMOND ET AL., supra note 184, at 5; Preventive Health, supra note 194.

196 GREENE, supra note 184.

197 REDMOND ET AL., supra note 184, at 5; Aimee Miles, Medicaid to Offer Rewards for Healthy Behavior, KAISER HEALTH NEWS (Apr. 11, 2011), http://www.kaiserhealthnews.org/stories/2011/april/08/medicaidincentives.aspx; GREENE, supra note 184, at 8 .

198 Blumenthal et al., supra note 14 , at 499 .

199 Id.

200 GREENE, supra note 165. 
Consistent with other data regarding the impact of incentives, the evaluation found that "[t] he largest increase in adherence occurred with children requiring only one annual visit" with gains declining for each additional recommended visit per year. 201

Beginning in 2006, West Virginia took additional steps to condition the terms of health-care coverage to medical and lifestyle compliance. Abandoning its original benefits package, West Virginia now has two tiers of Medicaid benefits: a default package referred to as "Basic," and a more robust plan referred to as "Enhanced." 202 However, the "Basic" plan offers fewer benefits than its predecessor. ${ }^{203}$ Recipients could access the Enhanced package if they "sign and conform to an agreement with the State that they will engage in certain behaviors." 204 Participating recipients agree to attend health improvement programs as directed by their health care providers, report on-time for recommended check-ups and other appointments, take prescribed medications as directed, use the hospital emergency room only for emergencies, and "do [their] best to stay healthy." 205

Some of the benefits included in the Enhanced Plan but not the Basic plan simply amount to coverage of wellnessrelated services such as programs like weight management, smoking cessation, diabetes education, nutritional

201 Blumenthal et al., supra note 14, at 499.

202 Sheryl Mitnick et al., Ethical Considerations for the Use of Patient Incentives to Promote Personal Responsibility for Health: West Virginia Medicaid and Beyond, AM. Coll. OF Physiclans 3 (2010), http://www.acponline.org/running_practice/ethics/issues/policy/personal _incentives.pdf.

203 Thomas J. Parisi, The Onus Is on You: Wellness Plans and Other Strategies Being Employed for Patients to Take Ownership of Their Health, 13 QUINNIPIAC HEALTH L.J. 243, 269-70 (2010). However, some beneficiaries (those over sixty-five, disabled, or in foster care at the time of the reforms) were allowed to keep the old benefits plan. Robert Steinbrook, Imposing Personal Responsibility for Health, 355 NEW ENGL. J. MED. 753, 754 (2006).

204 REDMOND ET AL., supra note 184, at 4.

205 Steinbrook, supra note 203, at 775. 
counseling, and substance-abuse treatment. ${ }^{206}$ Other benefits, however, are unrelated to wellness services and offer significantly more comprehensive access to health care. These include more comprehensive prescription-drug, transportation, skilled nursing, and mental-health-care benefits. 207 Notably, many services crucial to appropriate management of chronic disease are covered only under the Enhanced Plan, including patient-centered diabetes management and pulmonary rehabilitation services. 208 To maintain these benefits, recipients are required to comply with the Health Improvement Plan. Compliant recipients are also rewarded with credits placed in a "Healthy Rewards Account," which can be used to purchase services not otherwise covered by Medicaid, such as gym memberships and healthy foods. ${ }^{209}$

An assessment published in 2013 found that only $10 \%$ of eligible adults have enrolled in the Enhanced Plan, 210 meaning that the vast majority were simply downgraded into less comprehensive health-care coverage. Those who are enrolled in the Enhanced Plan have more office visits and are more likely to take prescribed medications than those who did not enroll. ${ }^{211}$

\section{Medicaid Incentives for the Prevention of Chronic Disease Grant Program}

New federal grants established under the ACA are providing further support for states to experiment with

206 Mitnick et al., supra note 202, at 3; Steinbrook, supra note 203.

207 REDMOND ET AL., supra note 184, at 4; DEP'T OF HEALTH AND Human Res., Chapter 527 Covered Services, Limitations, AND EXCLUSIONS FOR MOUNTAIN HEALTH CHOICES 12-43 (2009) [hereinafter CHAPTER 527], available at http://www.dhhr.wv.gov/bms/Documents/ bms_manuals_Chapter_527MountainHealthChoices.pdf at 12-43 (describing terms of coverage under the Basic and Enhanced Plans).

208 CHAPTER 527, supra note 207, at 27-43 (describing several preventive and disease management benefits available only under the Enhanced Plan).

209 Robert Steinbrook, supra note 203 , at 754.

210 Blumenthal et al., supra note 14 , at 500.

211 Id. 
incentive-based wellness programs aimed at tobacco cessation and weight, cholesterol, and blood-pressure management, and diabetes prevention and management. ${ }^{212}$ The statutory provision specifies that grants should be awarded to states "to carry out initiatives to provide incentives to Medicaid beneficiaries who-(i) successfully participate in a [wellness program]; and (ii) upon completion of such participation, demonstrate changes in health risk and outcomes, including the adoption and maintenance of healthy behaviors by meeting specific targets." 213 This language clearly contemplates outcomebased health-contingent programs. Furthermore, the statute mandates that recipient states "validate changes in health risk and outcomes with clinical data, including the adoption and maintenance of health behaviors by such beneficiaries" and "to the extent practicable, establish standards and health status targets for Medicaid beneficiaries participating in the program and measure the degree to which such standards and targets are met."214 At least one commentator expressed concern that "[w]hat counts as a permissible incentive is not specified in the Act," leaving the door open for states to "try to use more coercive incentives than would be permitted in private health plans" in response to the statutory requirement that the programs "validate' beneficiary progress." 215

In 2011, DHHS created the Medicaid Incentives for the Prevention of Chronic Disease ("MIPCD") grant program to provide states with a total of $\$ 85$ million over five years to "test the effectiveness of providing incentives directly to Medicaid beneficiaries ... who participate in the MIPCD prevention programs, and change their health risks and

212 Patient Protection and Affordable Care Act, Pub. L. 111-148, 124 Stat. 119, 562, § 4108(a)(3) (2010).

213 Id. $\S 4801(\mathrm{a})(1)(\mathrm{A})$.

214 Id. $\S 4108(\mathrm{c})$.

215 Wendy Mariner, The Affordable Care Act and Health Promotion: The Role of Insurance in Defining Responsibility for Health Risks and Costs, 50 DUQ. L. REV. 271, 287 (2012). 
outcomes by adopting healthy behaviors."216

The ten programs receiving funding feature a strong emphasis on the responsibility of the state to provide coverage of wellness-related services (such as smoking cessation or weight management programs). For example, Wisconsin's program features provision of tobacco-cessation counseling and education for health care providers regarding the resources available to Medicaid beneficiaries. $^{217}$ New Hampshire's program randomizes participants into programs that cover gym membership, gym membership plus sessions with a personal fitness trainer, Weight Watchers ${ }^{\mathrm{TM}}$, or Weight Watchers ${ }^{\mathrm{TM}}$ plus gym membership and personal trainer sessions. ${ }^{218}$

Most of the programs provide small financial incentives unrelated to the terms of coverage for participation only. ${ }^{219}$ One state, Texas, provides a larger incentive in the form of a flexible spending account. ${ }^{220}$ All of the programs offer

216 See MIPCD: The States Awarded, CTRS. FOR MEDICARE \& MEDICAID SERVS., http://innovation.cms.gov/initiatives/MIPCD/MIPCDThe-States-Awarded.html (last visited Apr. 26, 2014), archived at http://perma.cc/V523-R2F4.

217 CTRS. FOR MEdicARE \& MEDICAID SERvs., MIPCD State SUMMARY: WISCONSIN [hereinafter MIPCD WISCONSIN], available at http://innovation.cms.gov/Files/x/MIPCD-WI.pdf, archived at http://perma.cc/CG4D-U2K7.

218 CTRS. FOR MEDICARE \& MEDICAID SERVS., MIPCD STATE SUMMARY: NEW HAMPSHIRE [hereinafter MIPCD NEW HAMPSHIRE], available at http://innovation.cms.gov/Files/x/MIPCD-NH.pdf, archived at http://perma.cc/3M53-ZQ55.

219 For example, California's program provides $\$ 20$ to reward Medicaid beneficiaries who call a helpline, complete the intake protocol, and participate in counseling sessions. CTRS. FOR MEDICARE \& MEDICAID SERVS., MIPCD STATE SUMmaRY: CALIFORNIA, available at http://innovation.cms.gov/Files/x/MIPCD-CA.pdf, archived at http://perma.cc/6J4F-887W; Hawaii's program offers $\$ 25$ to beneficiaries who attend the first session of a smoking cessation, behavioral health counseling, or diabetes education program. CTRS. FOR MEDICARE \& MEDICAID SERVS., MIPCD STATE SUMMARY: HAWAII, available at http://innovation.cms.gov/Files/x/MIPCD-HI.pdf, archived at http://perma.cc/KJ48-Y5Y6.

220 MIPCD State Summary: Texas, CTR. FOR MEDICARE \& MEDICAID SERvS., available at http://innovation.cms.gov/Files/x/MIPCD-TX.pdf, archived at http://perma.cc/5ZA4-SGN2. 
participation-dependent incentives, while six of the ten programs offer some form of results-based incentive. ${ }^{221}$ Of those six, only three are for an outcome other than smoking cessation, ${ }^{222}$ and only two appear to involve clinical measurement (as opposed to self-report) as a means for validating health outcomes. ${ }^{223]}$

221 Programs in Wisconsin, New Hampshire, and Connecticut offer rewards for actual smoking cessation. MIPCD WISCONSIN, supra note 218; MIPCD NEW HAMPSHIRE, supra note 218; CTRS. FOR MEDICARE \& MEDICAID SERVS., MIPCD STATE SUMMARY: CONNECTICUT [hereinafter MIPCD CONNECTICUT], available at http://innovation.cms.gov/Files/x/ MIPCD-CT.pdf, archived at http://perma.cc/TA57-RU8Q. New York's program offers rewards for smoking cessation and for specified outcomes with regard to blood pressure, weight, and glycated hemoglobin (a marker indicative of diabetes disease management). CTRS. FOR MedicARE \& MEDICAID SERVS., MIPCD STATE SumMaRY: NEW YoRK [hereinafter MIPCD NEW YORK], available at http://innovation.cms.gov/Files/x/MIPCD-NY.pdf, archived at http://perma.cc/Z5V6-9Q6S. Nevada's program, which is aimed at reducing weight, cholesterol, and blood pressure and at managing and preventing diabetes offers incentives for achievement of unspecified "improved health outcomes." CTRS. FOR MEDICARE \& MEDICAID SERVS., MIPCD STATE SUMMARY: NEVADA [hereinafter MIPCD NEVADA], available at http://innovation.cms.gov/Files/x/MIPCD-NV.pdf, archived at http://perma.cc/QZ5B-6N7Z. Minnesota's program, which is aimed at weight loss, offers rewards for unspecified "goal attainment and goal maintenance." CTRS. FOR MEDICARE \& MEDICAID SERVS., MIPCD STATE SUMMARY: MINNESOTA [hereinafter MIPCD MINNESOTA], available at http://innovation.cms.gov/Files/x/MIPCD-MN.pdf, archived at http://perma.cc/662J-8E83.

222 MIPCD WISCONSIN, supra note 217; MIPCD NEW HAMPSHIRE, supra note 218; MIPCD CONNECTICUT, supra note 221; MIPCD NEW YoRK, supra note 221; MIPCD NEVADA, supra note 221; MIPCD Minnesota, supra note 221.

223 Connecticut's program offers a $\$ 15$ reward for each negative result on a breathalyzer test that detects smoking in the previous fortyeight hours. MIPCD CONNECTICUT, supra note 221. New York's program offers rewards for "decreasing or maintaining a decreased systolic blood pressure by $10 \mathrm{mmHg}$ or achieving another clinically appropriate target;" for "decreasing [glycated hemoglobin] by 0.6 percent or maintaining a level of 8.0 percent or less", or for "losing or maintaining a reduced weight." MIPCD NEW YORK, supra note 221. 


\section{Post-ACA Medicaid Waiver Decisions}

The Supreme Court's 2012 decision making the Medicaid expansion optional for states ${ }^{224}$ has given states even more bargaining power in seeking flexibility from CMS through waivers. ${ }^{225}$ Some of these waiver requests include the use of incentive-based wellness programs.

In 2013, CMS approved a new section 1115 waiver to allow Florida to fully privatize its Medicaid program, shifting nearly all of the state's Medicaid recipients into managed care plans operated by private insurance companies. ${ }^{226}$ Information provided by the state regarding this new demonstration project specifies that the managed care plans "will also establish programs to encourage and reward healthy behaviors" for smoking cessation, weight loss and alcohol or substance abuse recovery. 227

As part of a compromise reached in the Iowa state legislature over whether to accept the ACA's Medicaid expansion, the state sought section 1115 waivers to allow it to experiment with two new ways of covering adults aged nineteen through $64,{ }^{228}$ many of whom are newly eligible for Medicaid under the ACA expansion. The state's proposal

224 Nat'l Fed'n Indep. Bus. v. Sebelius, 132 S. Ct. 2566 (2012).

225 ROBERT Alt \&NATHANIEL STEWART, BUCKEYE INSTITUTE FOR Pub. Policy SOlutions, MEdiCAID WaIVERS ARE TEMPorary, EXPANSION IS FOREVER (2013), available at https://www.mackinac.org/archives/2013/s2013-06.pdf, archived at http://perma.cc/8CXF-FPGF.

226 JOAN ACKLER \& JACK HOADlEY, JESSE BALl DUPONT Fund, MEDICAID MANAGED CARE IN FLORIDA (2013), available at http://www.dupontfund.org/wp-content/uploads/2013/10/medicaid-brieffall-2103.pdf, archived at http://perma.cc/C23K-EGAJ.

227 Fla. AgENCY FOR HEALth CARE ADMIN., Florida MaNaged MEDICAL AssistanCE PROGRAM: AN OverVIEW 9 (Feb. 2013), available at http://www.ahca.myflorida.com/Medicaid/statewide_mc/pdf/mma/Overview_ of_Managed_Medical_Assistance_program_02-12-2013.pdf, archived at http://perma.cc/M2GJ-YNEV.

228 Certain individuals-those with disabling mental disorders, chronic substance abuse disorders, serious and complex medical conditions, physical, intellectual or developmental disability-would be exempt from both plans and would be enrolled in a traditional Medicaid plan. 
for two distinct plans was approved by CMS in December 2013 (along with a similar proposal submitted by Michigan). Under Iowa's "Marketplace Choice Plan," adults living at between $101 \%$ and $133 \%$ FPL are be enrolled in commercial health plans available through the state's health insurance Exchange (purchased with federal funds), rather than being enrolled in the public Medicaid program. ${ }^{229}$ The state's second waiver application for the "Iowa Wellness Plan,"230 under which adults between 50\% and 100\% FPL will be charged monthly premiums amounting to as much as $5 \%$ of their income, with a "waiver" available as a reward for completion of wellness activities was also approved. The premiums will not be charged to any beneficiaries during the first year, but any beneficiary who has not completed a health risk assessment and clinical exam by the end of 2014 will be charged monthly premiums beginning in 2015. After 2014, additional "wellness activities" will be required to avoid monthly premiums. As of this writing, a third waiver request tied to the Medicaid expansion and incorporating personal responsibility for wellness incentives, submitted by Pennsylvania, was still pending review.

Other states have indicated interest in similar approaches and are certainly taking notice of recent CMS decisions. ${ }^{231}$ For example, the governor of Idaho has indicated that he would only consider expanding Medicaid

229 IOWA DeP'T OF Health SERvs., Iowa MarketPlace Choice PLAN 1115 WAIVER APPLICATION (Aug. 2013), available at http://www.dhs.state.ia.us/uploads/IAMktplaceChoice1115_Final.pdf , archived at $\mathrm{http}: / /$ perma.cc/W7GF-CZ6G.

230 IOWA DEP'T OF Health SeRvS., IOWA Wellness Plan 1115 WAIVER APPLICATION (2013), available at http://www.dhs.state.ia.us/ uploads/IAWellnessPlan1115_Final.pdf, archived at http://perma.cc/ K4S6-TP5Z.

231 See, e.g., Kevin Miller, Senator Rethinks Bill to Deny Health Care to Smokers, BANGOR DAILY News (Mar. 1, 2011, 7:58 PM), http://bangordailynews.com/2011/03/01/health/senator-rethinks-billto-deny-health-care-to-smokers/ (reporting that Senator Tom Saviello introduced a bill to prohibit smokers from receiving Maine health care benefits in order to start a dialogue about the cost smokers place on Maine taxpayers), archived at http://perma.cc/33UL-FDQ9. 
eligibility if there were some provision for "requir[ing] more personal responsibility and better health outcomes." The Governor's statements indicate that he is clearly contemplating a punitive approach: "If you're smoking, you gotta quit smoking ... and if you don't quit smoking, some part of the benefit, or all of it, goes away. If you've got a history of diabetes in your family, and you're told to change a certain lifestyle, and you don't do it, then you don't get [benefits] anymore."232 CMS approval of the Iowa and Michigan plans might be taken as evidence that the agency is quite comfortable with incentive-based wellness programs that make access to health care contingent upon healthy behavior. An argument could perhaps even be made that while DHHS and other implementing agencies have taken a stance protective of individuals who are privately insured, they have failed to extend the same protection to those poor enough to qualify for Medicaid. It seems more likely, however, that the CMS approvals are simply the product of state's assuming a superior negotiating position as a result of the Supreme Court's 2012 decision. Expanding Medicaid eligibility in Iowa and Michigan while allowing the imposition of premiums and cost-sharing terms that penalize individuals for non-compliance with wellness goals might easily be weighed as a better alternative to having the state refuse the expansion. ${ }^{233}$ In any case, rigorous evaluation of these demonstration projects could provide useful information about the impact of wellness incentives for Medicaid recipients.

232 Audrey Dutton, Idaho Gov. Otter Wants More Personal Accountability in Medicaid, IDAHO STATESMAN (May 30, 2013) http://www.idahostatesman.com/2013/05/30/2595854/carrots-and-sticksfor-medicaid.html, archived at http://perma.cc/B4SS-BD4C.

233 See, e.g., Tim Martin, Michigan House Republicans Introduce Broad Medicaid Plan with Time Limits, Expanded Coverage, MLIVE.COM (May 9, 2013, 7:49 PM), http://www.mlive.com/politics/ index.ssf/2013/05/michigan_house_republicans_det.html (reporting that Michigan's legislature proposed expanding the population of those eligible for Medicaid in exchange for implementing personal responsibility measures that would affect the entire Medicaid population), archived at $\mathrm{http}: / /$ perma.cc/68YP-2H6V. 


\section{CONCLUSION}

Recent agency actions implementing a collection of ACA reforms designed to promote personal responsibility for wellness indicate appropriate skepticism toward an approach that places the onus on individuals to change their behavior, without necessarily making it more feasible for them to do so. The agency-commissioned RAND Report provides a much-needed antidote to hyperbolic wellness industry claims regarding the potential public-health benefits and cost savings of incentive-based programs. It also provides the foundation for expertise-driven administrative implementation of ACA wellness provisions. The 2013 Final Rule on group-based wellness programs sharply curtails the most punitive approaches and should offer greater protection than its predecessor against the use of wellness incentives as a pretext for shifting health-care costs to individuals who are perceived as unhealthy. The individual market demonstration project and small business grant program are less far along in their implementation, but they create promising opportunities for HHS to continue to emphasize the importance of insurer and employer responsibility interventions such as enhanced coverage for wellness-related goods and services and worksite improvements that facilitate healthier choices. It is encouraging that state programs receiving funds under the Medicaid wellness incentives grant program largely emphasize participation-only incentives, with minimal representation of biomarker-based rewards and no measures that tie the terms of coverage directly to wellness program engagement. The tilt of these funded programs toward payer responsibility may provide a clue as to the agency's likely response to pending waiver requests that would take a more punitive approach. Altogether, agency implementation of these provisions represents an important step in the right direction. But continued vigilance is necessary to ensure that third-party payers do not use wellness reforms to undermine the ACA's goals with respect to health care access and disease prevention. 
Beyond curtailing undesirable practices (from a public health standpoint) by third-party payers, the question remains whether public-health advocates might be able to enlist those payers in their efforts to tackle some of the most powerful, upstream drivers of chronic diseases like diabetes and heart disease. I have argued elsewhere that we are nearing a political crossroads in the effort to prevent obesity-related disease. ${ }^{234}$ Powerful industries are expending considerable resources to sway policymakers at every level of government away from interventions aimed at creating work, school, and marketplace environments that are more conducive to healthy living. Personalresponsibility measures are generally more politically palatable and fiscally conservative and they have the backing of the wellness industry, which stands to profit from their implementation. Ironically, local governmentswho, unlike states and the federal government, do not play a significant role in paying health-care costs-have been among the most innovative pioneers in this effort. ${ }^{235}$ The federal government, which funds the Medicare program in its entirety, has perhaps the greatest financial stake in chronic-disease prevention, but federal action is stymied by a dysfunctional legislature. State legislatures are poised to become a key battleground, but many of them are blocking local efforts through preemption legislation rather than implementing meaningful reforms. ${ }^{236}$ A powerful new ally-in the form of private insurers and state-government payers-could provide leverage for public health advocates at a crucial time.

234 See Wiley, Shame, supra note 18.

235 See Paul A. Diller, Why Do Cities Innovate in Public Health? Implications of Scale and Structure, 91 WASH. L. REV. (forthcoming 2014).

236 See, e.g., Bill Lueders, Banning Local Rules is National Strategy, WisconsinWatch.org (May 28, 2013), http://www.wisconsinwatch.org/ 2013/05/28/banning-local-rules-is-national-strategy/. 

Notes 
